TRAVELTIME AND DISPERSION DATA, INCLUDING ASSOCIATED

DISCHARGE AND WATER-SURFACE ELEVATION DATA,

KANAWHA RIVER, WEST VIRGINIA, 1991

By Jeffrey B. Wiley

U.S. GEOLOGICAL SURVEY

Open-File Report 93-121

Prepared in cooperation with the

VIRGINIA ENVIRONMENTAL ENDOWMENT, MARSHALL UNIVERSITY RESEARCH CORPORATION,

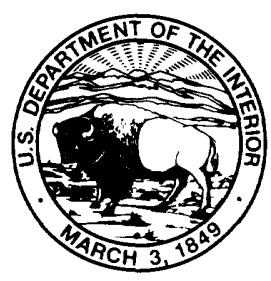
and the

WEST VIRGINIA DEPARTMENT OF ENVIRONMENTAL PROTECTION

Charleston, West Virginia 


\section{U.S. DEPARTMENT OF THE INTERIOR BRUCE BABBITT, Secretary \\ U.S. GEOLOGICAL SURVEY \\ Robert M. Hirsch, Acting Director}

For additional information write to:

District Chief

U.S. Geological Survey, WRD 603 Morris Street

Charleston, WV 25301
Copies of this report can be purchased from:

U.S. Geological Survey

Earth Science Information Center--Open-File Reports Section Box 25286, MS 517

Denver Federal Center

Denver, CO 80225 


\section{CONTENTS}

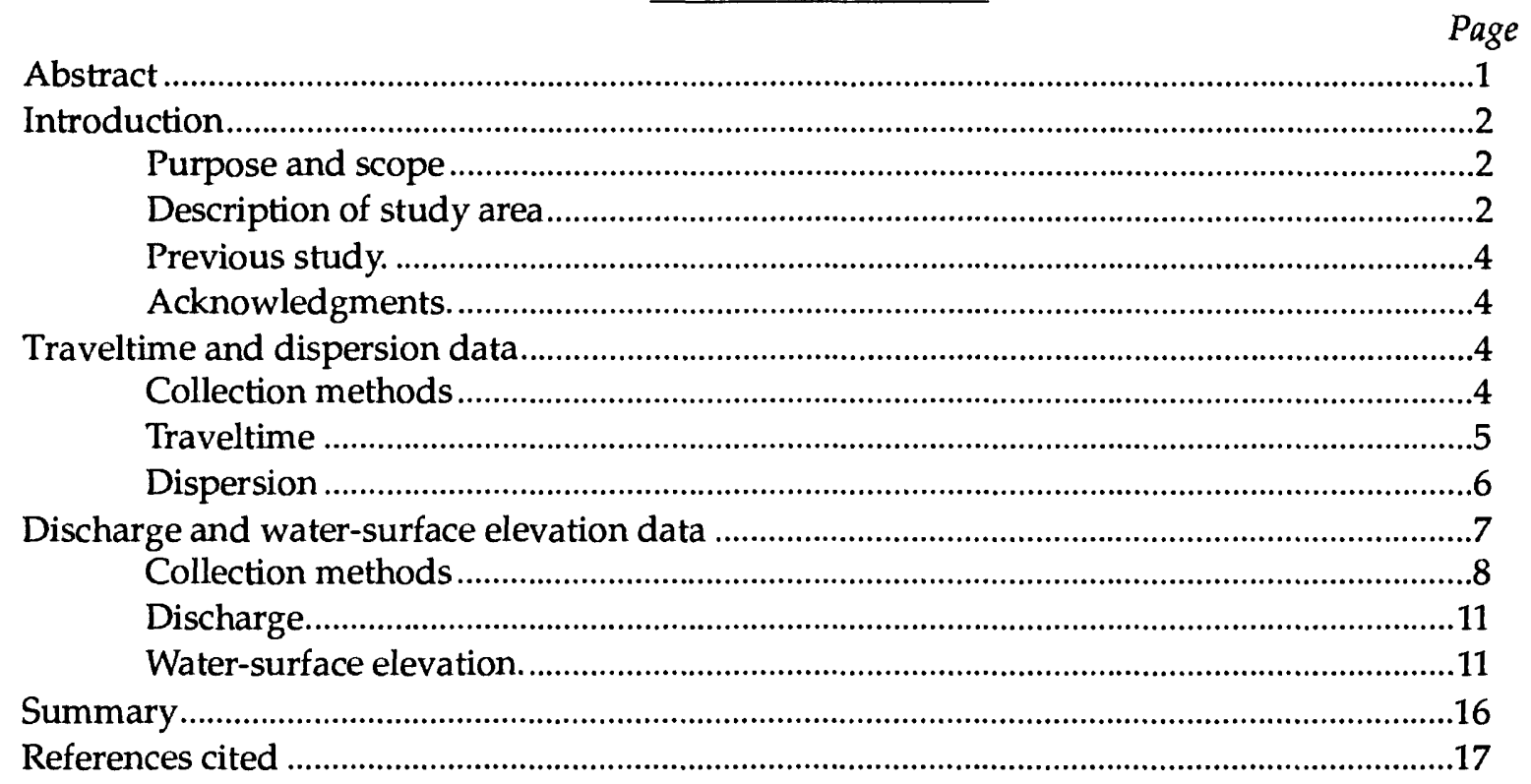

\section{ILLUSTRATIONS}

Figure 1. Map showing location of the Kanawha River study area.

2-4. Graphs showing observed time-concentration curves for the dye injection at:

2. Hawks Nest Dam.

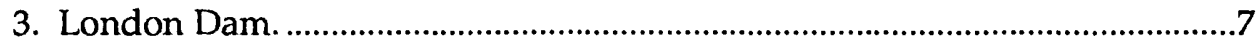

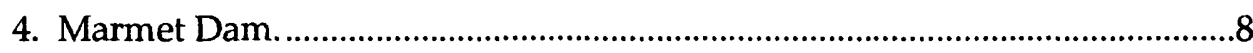

5. Graph showing cumulative traveltimes for the 1991 dye study......................11

6-7. Graphs showing daily mean discharges for the Kanawha River:

6. At Kanawha Falls and Charleston, June 24 through July 3, 1991 ................13

7. From the Gauley, Elk, and Coal Rivers, June 24 through July 3, 1991 ........13

8. Graph showing Kanawha River profile, navigable section.................................14

9-12. Graphs showing daily mean water-surface elevations from June 24 through July 3, 1991, at:

9. Winfield and Point Pleasant in the Gallipolis pool.....................................14

10. Winfield, Charleston, and Marmet in the Winfield pool. ............................15

11. Marmet and London in the Marmet pool...................................................15

12. London in the London pool.......................................................................... 


\title{
TRAVELTIME AND DISPERSION DATA, INCLUDING ASSOCIATED DISCHARGE AND WATER-SURFACE ELEVATION DATA, KANAWHA RIVER, WEST VIRGINIA, 1991
}

\author{
By Jeffrey B. Wiley
}

\begin{abstract}
This report presents results of a study by the U.S. Geological Survey, in cooperation with the Virginia Environmental Endowment, Marshall University Research Corporation, and the West Virginia Department of Environmental Protection, to evaluate traveltime of a soluble dye on the Kanawha River.

The Kanawha River originates in south-central West Virginia and flows northwestward to the Ohio River. Knowledge of traveltime and dispersion of a soluble dye could help river managers mitigate effects of an accidental spill.

Traveltime and dispersion data were collected from June 20 through July 4, 1991, when river discharges decreased from June 24 through July 3,1991 . Daily mean discharges decreased from $5,540 \mathrm{ft}^{3} / \mathrm{s}$ on June 24 to $2,790 \mathrm{ft}^{3} / \mathrm{s}$ on July 2 at Kanawha Falls and from $5,680 \mathrm{ft}^{3} / \mathrm{s}$ on June 24 to $3,000 \mathrm{ft}^{3} / \mathrm{s}$ on July 2 at Charleston. Water-surface elevations in regulated pools indicated a loss of water storage during the period.

A spill at Gauley Bridge under similar streamflow conditions of this study is estimated to take 15 days to move beyond Winfield Dam. Estimated time of passage (elapsed time at a particular location) at Marmet Dam and Winfield Dam is approximately 2.5 days and 5.5 days, respectively. The spill is estimated to spend 12 days in the Winfield pool.
\end{abstract}




\section{INTRODUCTION}

The Kanawha River originates at the confluence of the New River and Gauley River at Gauley Bridge in south-central West Virginia. From Gauley Bridge, the Kanawha River flows northwest through West Virginia to the Ohio River at Point Pleasant, West Virginia (fig. 1).

The Kanawha River provides water for municipalities and industries, and the river is used for transportation and recreation. Municipal and industrial intakes and outflows are scattered throughout the study area. Chemical-manufacturing plants are located along the upper two-thirds of the river. The river is used to transport chemical-manufacturing materials and coal from the regional coal fields. Recreational boating and fishing are common along the entire river.

Government and industry have successfully cooperated during the past 20 to 25 years to improve water quality (water quality had previously decreased because of municipal and industrial pollution). Water quality can be adversely affected if a contaminant is accidentally spilled. An accidental spill is possible during transportation of chemicals and toxic waste by pipeline, rail, highway, or barge on and near the river and its tributaries. Knowledge of the movement of a spill can help to minimize effects for private and industrial water users. For example, water intakes could be closed, and fishing and recreational uses could be restricted. Traveltime and dispersion data can help river managers to mitigate effects of an accidental spill of a soluble contaminant on river-water quality. Careful management of area dams could be used to change the characteristics of the contaminant cloud. Furthermore, these data can be used to calibrate or verify a water-quality transport model. This study was done in cooperation with the Virginia Environmental Endowment, Marshall University Research Corporation, and the West Virginia Department of Environmental Protection.

\section{Purpose and Scope}

This report presents traveltime and dispersion data for the Kanawha River from
June 24 through July 3, 1991, when discharges at Charleston ranged from $5,680 \mathrm{ft}^{3} / \mathrm{s}$ on June 24 to $3,000 \mathrm{ft}^{3} / \mathrm{s}$ on July 2 , and discharge and watersurface elevation data from June 20 through July 4. The study area is the main stem of the Kanawha River and $4.6 \mathrm{mi}$ of the New River (from the mouth of the New River to Hawks Nest Dam).

\section{Description of Study Area}

The Kanawha River originates at the confluence of the Gauley River and New River at Gauley Bridge (fig. 1). Gauley Bridge is located 96.6 river miles (RM) upstream from the mouth of the Kanawha River. The Gauley River has a drainage area of $1,414 \mathrm{mi}^{2}$ at the mouth (Mathes and others, 1982), and is regulated by Summersville Dam. The New River has a drainage area of $6,943 \mathrm{mi}^{2}$. The New River is regulated by Claytor Dam in Virginia, and Bluestone Dam and Hawks Nest Dam in West Virginia.

Hawks Nest Dam is located $4.6 \mathrm{mi}$ upstream from the mouth of the New River as measured through the Hawks Nest Aqueduct (Erwin, 1986). Hawks Nest Aqueduct is a 3.1-mi tunnel, dropping $162 \mathrm{ft}$, that circumvents approximately $5 \mathrm{mi}$ of the New River. The tunnel, constructed between 1930 and 1932, has inside diameters between 31 and $46 \mathrm{ft}$. Part of the tunnel is lined with concrete, part is lined with steel, and part is unlined (Cherniack, 1986).

The Kanawha River has a drainage area of $12,233 \mathrm{mi}^{2}$ at the mouth. Tributaries with drainage areas greater than $50 \mathrm{mi}^{2}$ located between Gauley Bridge (RM 96.6) and the mouth (RM 0.0) are shown in figure 1, and include: Paint Creek, $123 \mathrm{mi}^{2}$, at RM 80.6; Cabin Creek, $72.7 \mathrm{mi}^{2}$, at RM 74.5; Elk River, 1,533 $\mathrm{mi}^{2}$, at RM 58.0; Coal River, $892 \mathrm{mi}^{2}$, at RM 45.7; Pocatalico River, $356 \mathrm{mi}^{2}$, at RM 39.2; Hurricane Creek, $76.5 \mathrm{mi}^{2}$, at RM 28.9; Eighteenmile Creek, $77.9 \mathrm{mi}^{2}$, at RM 18.6; and Thirteenmile Creek, $77.9 \mathrm{mi}^{2}$, at RM 11.9. Elk River is the only tributary that is regulated (by Sutton Dam).

Kanawha Falls is located approximately 1.4 mi downstream from the confluence of the Gauley and New Rivers (fig. 1). A diversion dam occupies part of the Kanawha River at this 


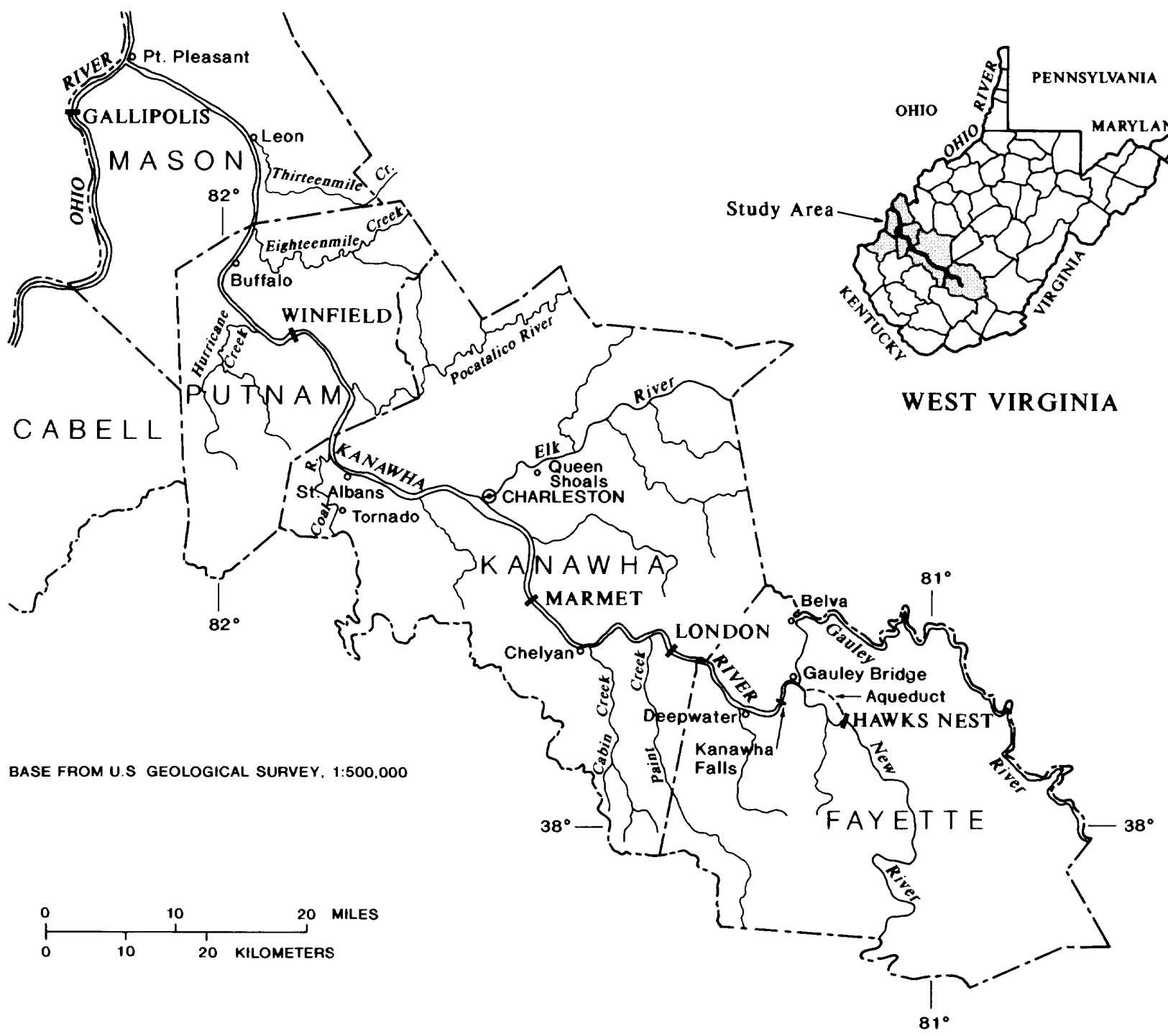

Figure 1.-Location of the Kanawha River study area (Modified from Appel, 1991, p. 3.)

point, forcing additional streamflow across a natural 8-ft falls. Low-head turbines have been installed in a powerhouse adjacent to the falls.

The river flows freely downstream for approximately the next $5 \mathrm{mi}$ until it reaches a series of navigation pools regulated by London,
Marmet, Winfield, and Gallipolis Dams. London (RM 82.8), Marmet (RM 67.7), and Winfield (RM 31.1) Dams are submerged weirs with tainter gates, and include navigation locks on the right bank and low-head turbines in a powerhouse on the left bank (U.S. Army Corps of Engineers, 1989). The Gallipolis Dam is on the 
Ohio River, approximately $5 \mathrm{mi}$ downstream from the mouth of the Kanawha River, and regulates streamflow in the lower Kanawha River (U.S. Army Corps of Engineers, 1990).

\section{Previous Study}

Traveltime and dispersion data were collected for this study area in August and October 1989 (Appel, 1991). In August 1989, dye was injected at Winfield Dam when river discharge was $4,500 \mathrm{ft}^{3} / \mathrm{s}$, and water samples were collected at locations between Winfield Dam and the mouth of the Kanawha River. In October 1989, dye was injected at Marmet Dam, London Dam, and Hawks Nest Aqueduct when river discharge ranged from $8,500 \mathrm{ft}^{3} / \mathrm{s}$ to $12,500 \mathrm{ft}^{3} / \mathrm{s}$ at Kanawha Falls and from $10,000 \mathrm{ft}^{3} / \mathrm{s}$ to $13,000 \mathrm{ft}^{3} / \mathrm{s}$ at Charleston. Water samples were collected at locations between Hawks Nest Aqueduct and Winfield Dam. Traveltime and dispersion data for the 1989 dye measurements were compiled from analysis of water samples for dye concentration.

\section{Acknowledgments}

The author wishes to thank the U.S. Army Corps of Engineers for regulating discharges, providing river-discharge forecasts, and allowing access to river-structure properties. Thanks also goes to the Elkem Metals Company for allowing access to Hawks Nest Dam, and to the Appalachian Power Company for operating lowhead turbines at dam structures to help with dye injections and ensuring steady discharges.

\section{TRA VELTIME AND DISPERSION DATA}

Traveltime and dispersion are two properties of the movement of water in a river. Horizontal and vertical velocity distributions, eddies, pools, and river bends are some characteristics of a river that affect traveltime and dispersion. River structures, such as bridges and dams, could also affect traveltime and dispersion. Traveltime and dispersion can be affected when regulation at a dam results in holding or releasing more water than is flowing into a controlled pool. Traveltime and dispersion in the general area of the structure can be affected if flow characteristics through the structure change because of changing gate settings and lockages.

\section{Collection Methods}

Measurements of traveltime and dispersion of a conservative-dye tracer are used to estimate the movement of water and waterborne solutes in a river system. Measurement techniques are well documented (Kilpatrick and Wilson, 1989; Hubbard and others, 1982). Usually, a fluorescent dye is injected into the river. Water samples are collected at various locations downstream, beyond the distance required for horizontal and vertical mixing. Methods of water-sample analysis have been described by Wilson and others (1986).

A slight modification of the standard procedure was employed for this study. A fluorometer was calibrated by diluting the dye in a three-step procedure to a $100 \mu \mathrm{g} / \mathrm{L}$ working solution, and diluting the working solution into various concentrations expected during the study. A dye lot with the specific gravity of 1.19 is used in the standard procedure. Specific gravity of the dye used in this study was 1.105 . In the standard procedure, 2,068 milliliters ( $\mathrm{mL}$ ) of water and $20 \mathrm{~mL}$ of dye are mixed in the first step of the three-step process to prepare the $100 \mu \mathrm{g} / \mathrm{L}$ working solution. In this study, $1,191 \mathrm{~mL}$ of water were used in the first step to compensate for the differences in specific gravity.

Slug injections in the Kanawha River can require more than $20 \mathrm{mi}$ to mix completely (from equations presented in Kilpatrick and Wilson, 1989). For this reason, all flows at lock-and-dam structures (except for leakage through the structure and normal lockages of river traffic) were routed through the turbines. By routing flows through the turbines, the stream width is temporarily reduced and the river turbulence is increased. Dye was injected as a slug at the upstream face of the dam in front of the turbine gates. This dye-injection technique distributed dye across the entire river within approximately 1 to $2 \mathrm{mi}$ (visual inspection by author), therefore reducing the mixing length. The slug injections 
at Marmet and London were $200 \mathrm{lb}$ and $75 \mathrm{lb}$ of 20-percent solution of rhodamine-WT dye, respectively.

Dye injection at the location farthest upstream was at the upstream face of the gates that regulate flows into Hawks Nest Aqueduct at Hawks Nest Dam on the New River. All flows in the New River were routed through the tunnel, except for approximately $100 \mathrm{ft}^{3} / \mathrm{s}$ necessary to maintain water quality in the $5 \mathrm{mi}$ of river circumvented by the tunnel. The slug injection at this location was $100 \mathrm{lb}$ of 20-percent solution of rhodamine-WT dye.

Selected river locations are identified in table 1, including those where water samples were collected. Dye concentrations of water samples are presented in tables 5 through 7 , which are found at the end of report.

\section{Traveltime}

Time-concentration curves were developed to identify traveltime and dispersion of dye injections (figs. 2-4). Traveltime of the leading edge, peak concentration, and trailing edge at locations for each dye injection can be determined from these graphs and from the data given in table 2. Reading from the $\mathrm{X}$-axis of figure 2, the leading edge of the dye cloud produced from the slug injection at Hawks Nest arrived at London Dam approximately 35 hours later and at Chelyan approximately 69 hours later (traveltimes of peak concentration and trailing edge can be determined similarly). Traveltimes for the injections at London and Marmet Dams can be determined from figure 3 and figure 4 , respectively.

Mixing length of the river was reduced by injecting dye upstream from the turbines. This procedure did not mix the dye completely at the injection location, and traveltimes are affected to locations downstream until complete mixing is achieved. Much of the effect of incomplete mixing can be accounted for when sample and injection locations are overlapped. Cumulative traveltimes are computed that assume only complete mixing (table 2). Cumulative traveltimes
Table 1.--Distance to selected locations in the study area

(Modified from Appel, 1991, p. 6)

\begin{tabular}{|c|c|}
\hline $\begin{array}{l}\text { Dista } \\
\text { miles } \\
\text { from } \\
\text { the K }\end{array}$ & $\begin{array}{l}\text { nce, in river } \\
\text { upstream } \\
\text { the mouth of } \\
\text { anawha Rive }\end{array}$ \\
\hline Mouth of Kanawha River & 0.0 \\
\hline Point Pleasant, Highway 2 bridge & .1 \\
\hline Confluence of Thirteenmile Creek & 11.9 \\
\hline Leon, public boat ramp & 12.1 \\
\hline Confluence of Eighteenmile Creek & 18.6 \\
\hline Buffalo, public boat ramp & 22.5 \\
\hline Confluence of Hurricane Creek & 28.9 \\
\hline Winfield Dam ${ }^{1}$ & 31.1 \\
\hline Confluence of Pocatalico River & 32.2 \\
\hline Confluence of Coal River & 45.7 \\
\hline Saint Albans, Highway 25 bridge $^{1}$ & 46.1 \\
\hline Charleston, Patrick Street bridge 1 & 56.4 \\
\hline Confluence of Elk River & 58.0 \\
\hline Charleston, 35th Street bridge 1 & 60.9 \\
\hline Marmet Dam $^{1}$ & 67.7 \\
\hline Chelyan, Highway 61 bridge $^{1}$ & 73.6 \\
\hline Confluence of Cabin Creek & 74.5 \\
\hline Confluence of Paint Creek & 80.6 \\
\hline London Dam ${ }^{1}$ & 82.8 \\
\hline Deepwater railroad bridge ${ }^{1}$ & 90.0 \\
\hline Kanawha Falls, Highway 13 bridge ${ }^{1}$ & 94.3 \\
\hline Kanawha Falls & 95.2 \\
\hline $\begin{array}{l}\text { Confluence of Gauley River and New River } \\
\text { Gauley Bridge, railroad bridge }\end{array}$ & 96.6 \\
\hline over New River ${ }^{1}$ & 97.8 \\
\hline $\begin{array}{l}\text { Elkem Metals Hydroelectric Power Plant } \\
\text { tailrace on New River }\end{array}$ & 98.1 \\
\hline $\begin{array}{l}\text { Hawks Nest Dam on New River } \\
\text { (through Hawks Nest Aqueduct) }\end{array}$ & 101.2 \\
\hline
\end{tabular}

${ }^{1}$ Water-sample collection location.

can be used to determine traveltimes between locations of different dye injections. For example, using figure 5, the traveltime of the trailing edge between Deepwater (collection location for the injection at Hawks Nest) and Saint Albans (collection location for the injection at Marmet Dam) is approximately 205 hours (231 hours - 26 hours $=205$ hours). Similarly, using figure 5, a spill at Gauley Bridge would be estimated to take about 15 days to pass Winfield Dam, and the spill 


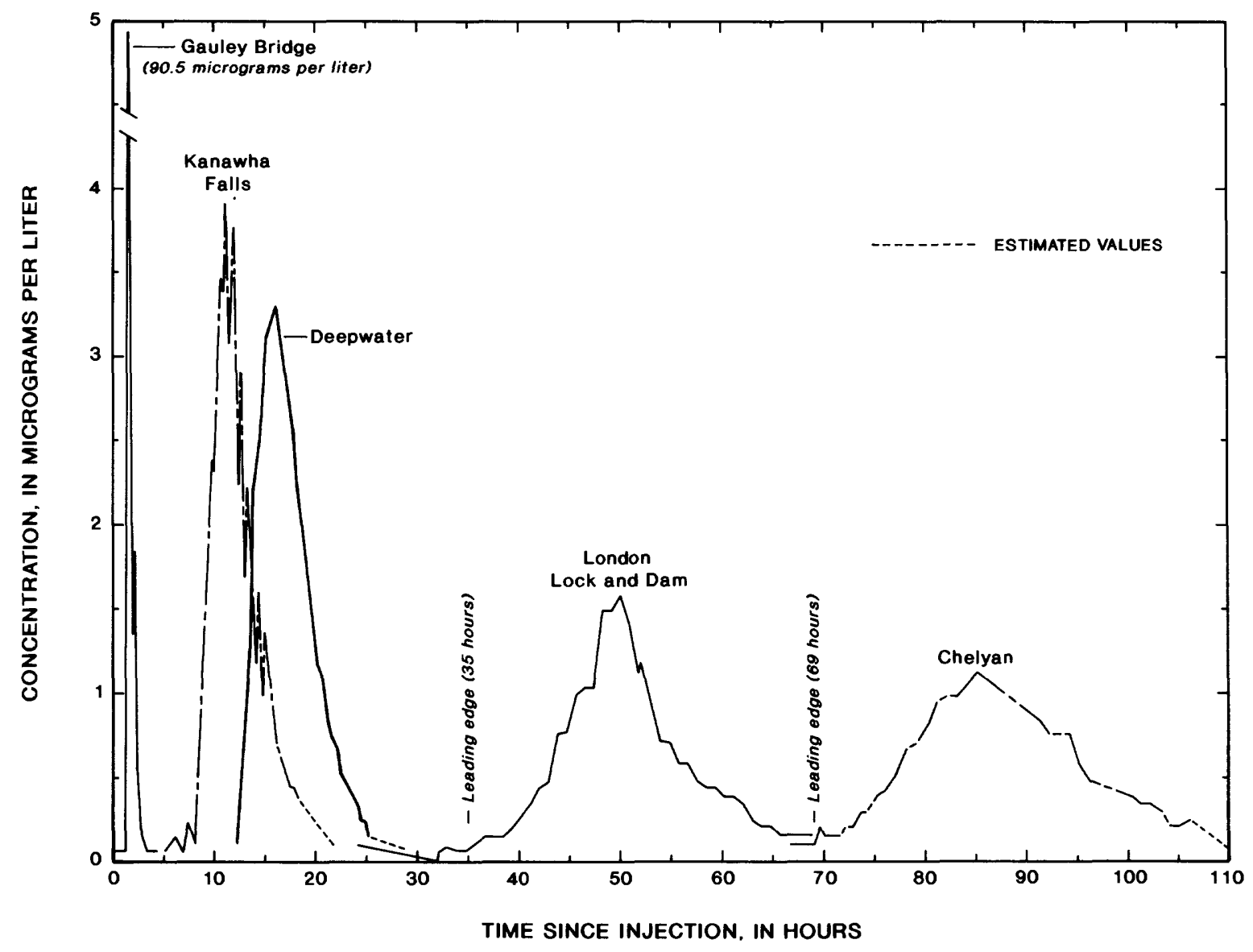

Figure 2.--Observed time-concentration curves for the dye injection at Hawks Nest Dam. (Injected at 1200 hours on June 25, 1991.)

would spend about 12 days in the Winfield pool. These cumulative traveltimes should be used as estimates only when river discharges are similar to flows of this study.

\section{Dispersion}

Time-concentration curves (figs. 2 - 4) illustrate stream dispersion. The peak concentration decreases as time since injection increases.
Dispersion is also indicated by time of passage (defined as the time of trailing edge minus the time of leading edge, table 3 ). Time of passage increases as time since injection increases. As shown in figure 5 and by the discussion in the previous section concerning a spill at Gauley Bridge being in the Winfield pool for about 12 days, the estimated time of passage at Marmet Dam is about 2.5 days and at Winfield Dam about 5.5 days. 


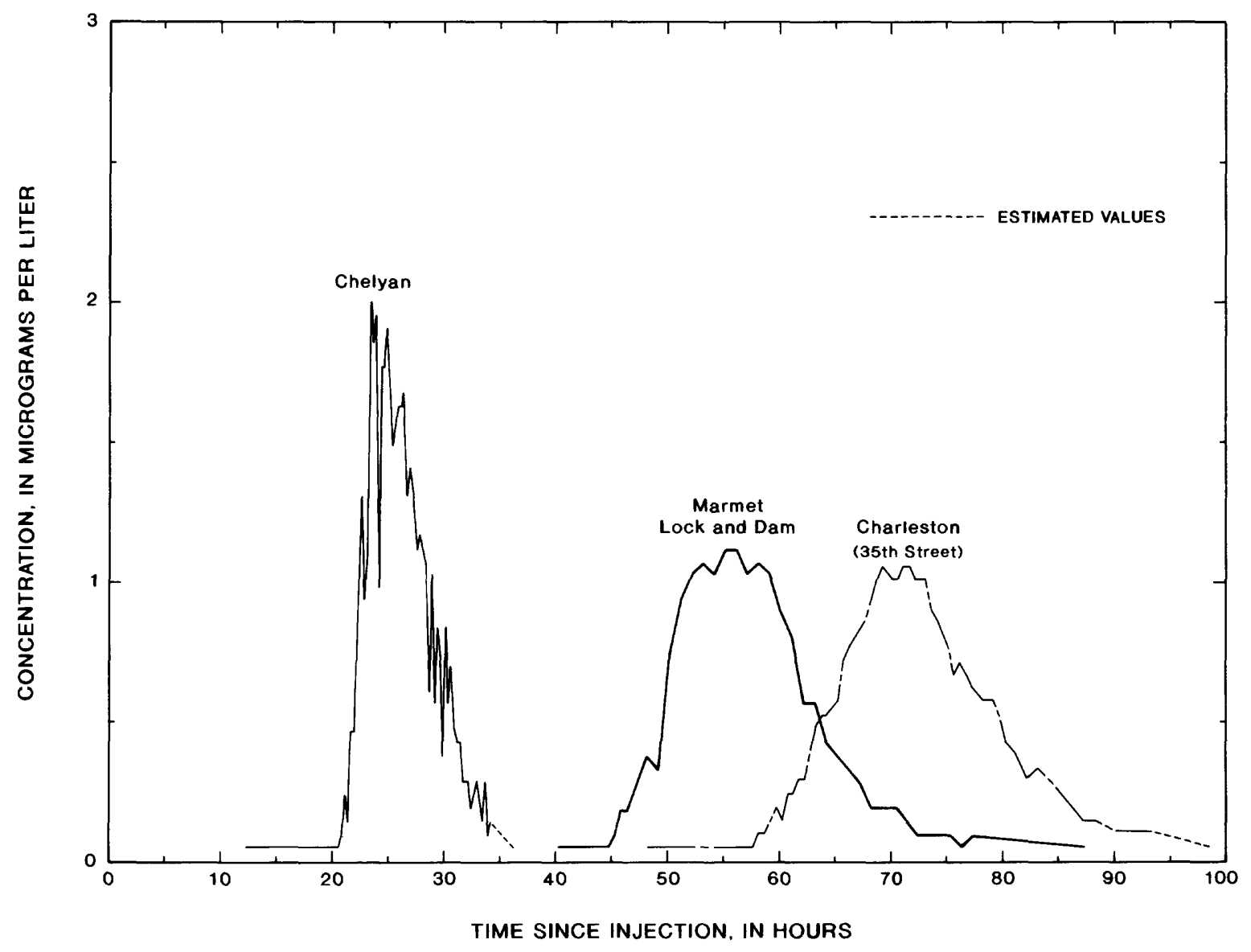

Figure 3.--Observed time-concentration curves for the dye injection at London Dam. (Injected at 1800 hours on June 24,1991 .)

Conservative-peak and unit-peak concentrations are shown in table 3 . The conservativepeak concentration is the observed-peak concentration adjusted for any dye loss, and the unitpeak concentration is the conservative-peak concentration expressed as a concentration per unit weight of discharge. Differences in the unitpeak concentrations between reaches are primar-ily due to differences in longitudinal dispersion. Conservative and unit-peak concentrations can be used to develop relations to predict peak concentrations at discharges where measurements are not made. Additional dye measurements are required to develop these relations.

\section{DISCHARGE AND WATER-SURFACE ELEVATION DATA}

Discharge data describe the volume of water moving per unit time in a river system. Because of river regulation in this river system, water- 


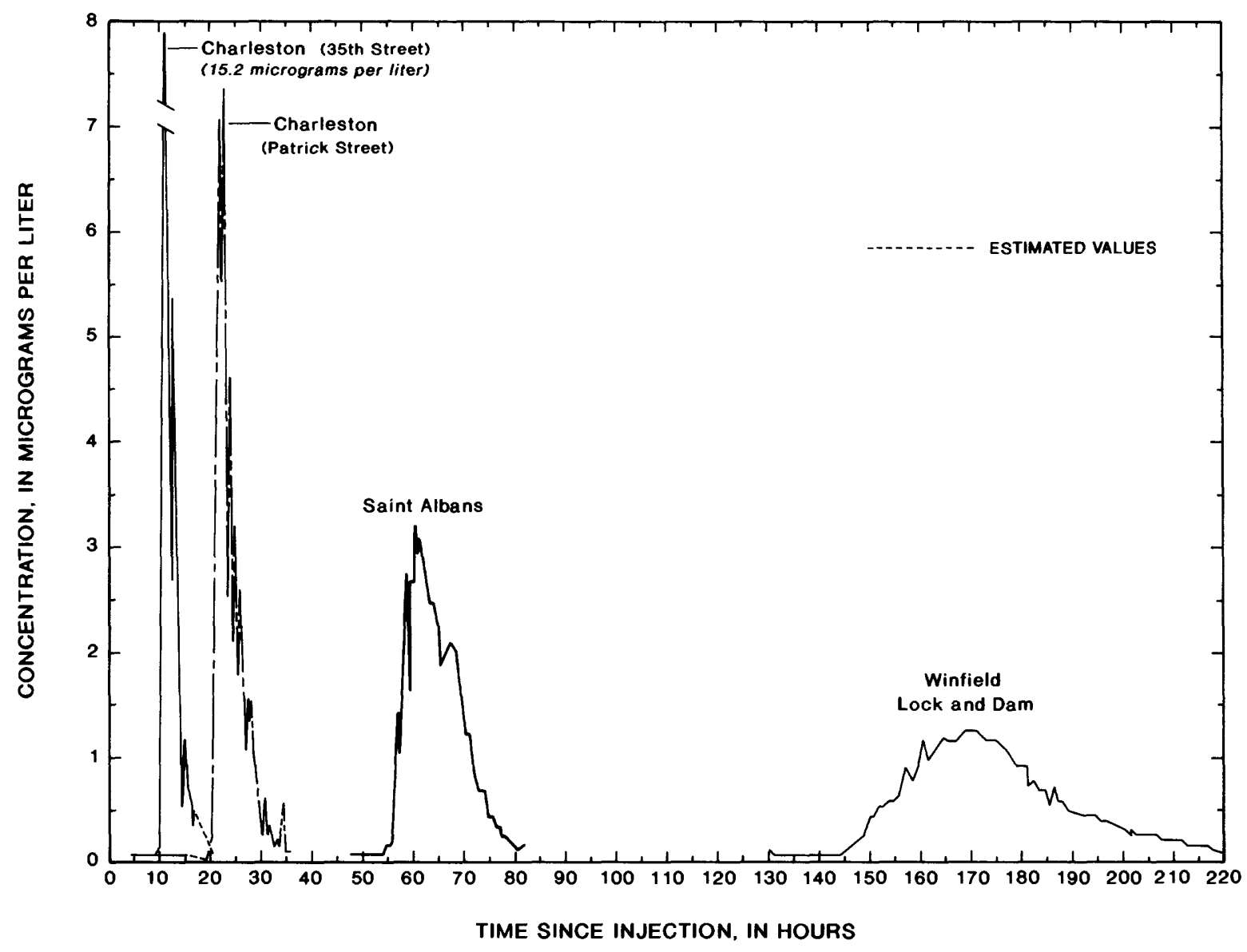

Figure 4.--Observed time-concentration curves for the dye injection at Marmet Dam. (Injected at 0700 hours on June 24, 1991.)

surface elevation data are necessary to account for changes in water storage. Changes in discharge and storage can affect traveltime and dispersion of a conservative solute in this river system.

\section{Collection Methods}

Discharge and water-surface elevation data are collected at established U.S. Geological Survey streamflow-gaging stations. Table 4 is a list of streamflow-gaging stations applicable to this study. Discharge and water-surface elevation data for the streamflow-gaging stations are measured by standard methods described by Rantz and others (1982). Daily mean discharge and water-surface elevation data collected for this study are presented in table 8 at the end of the report. 


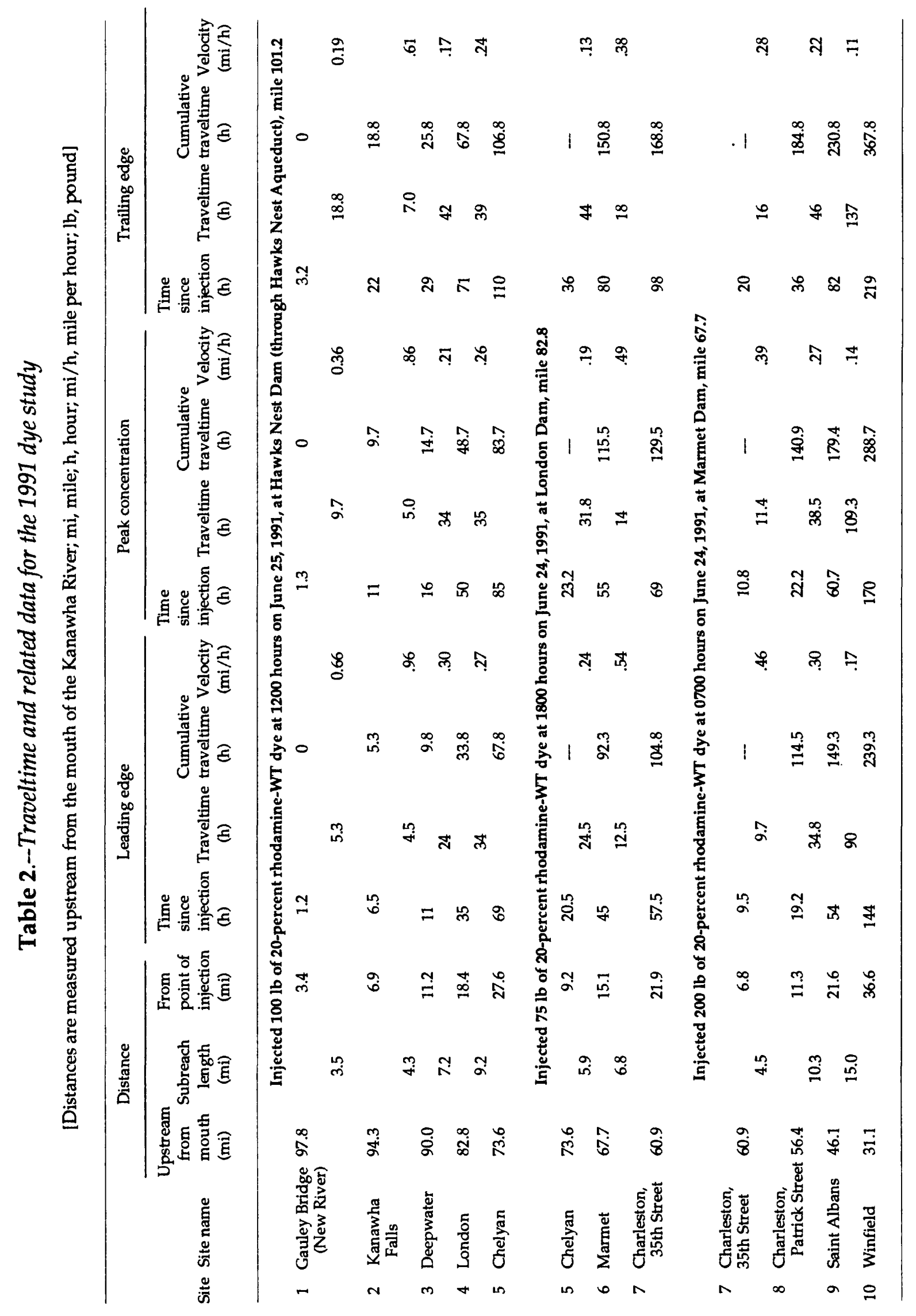




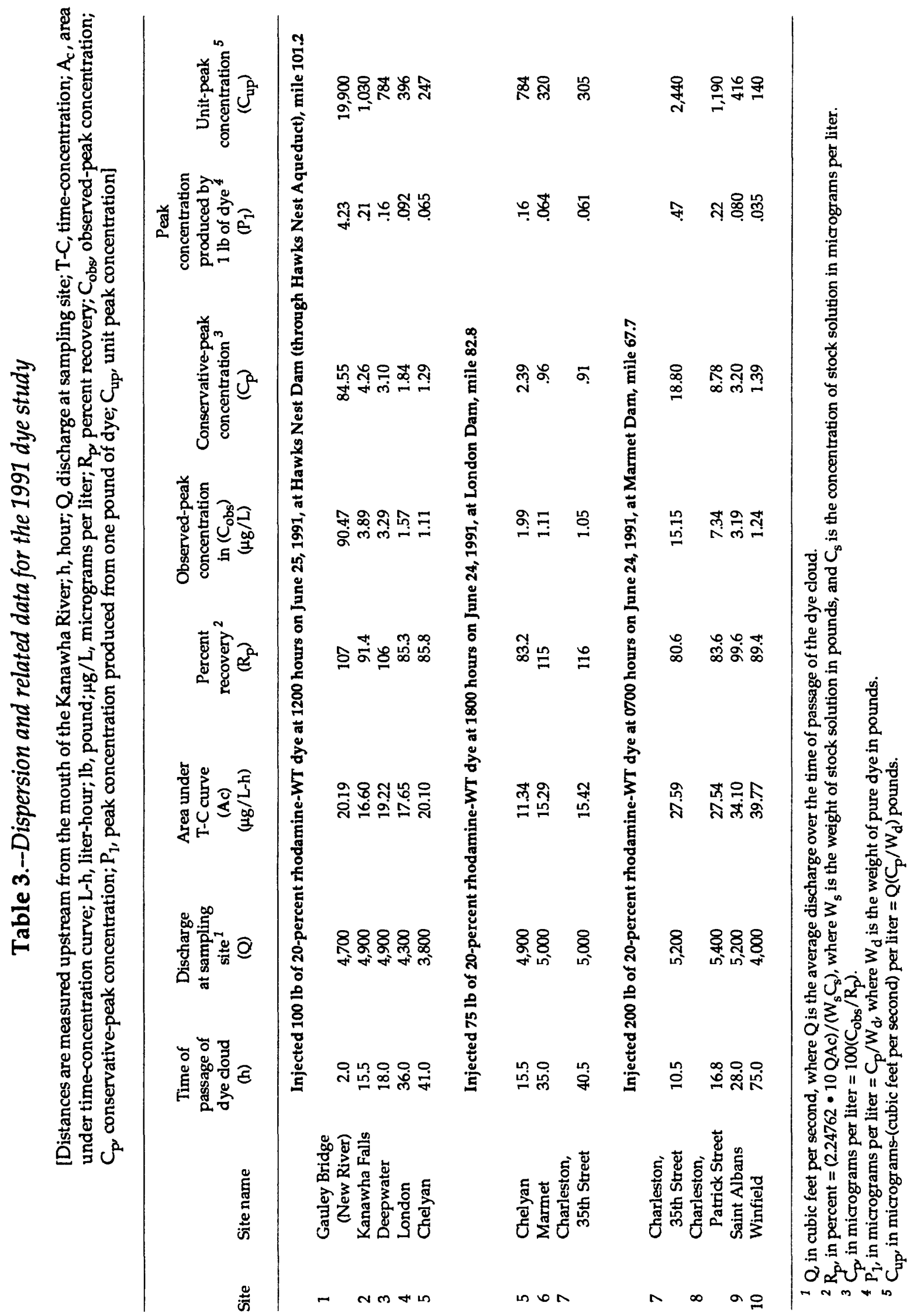




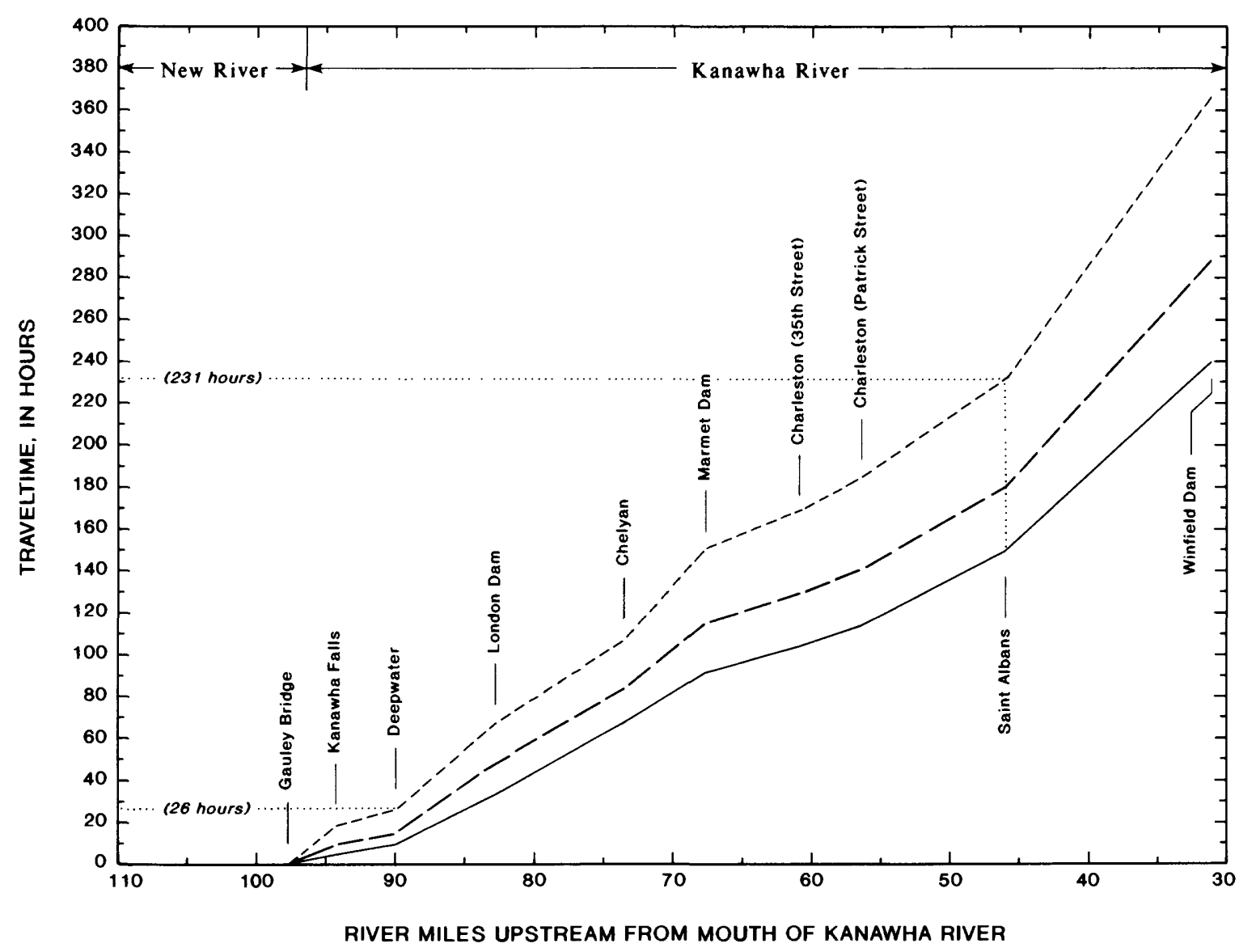

EXPLANATION

TRAILING EDGE

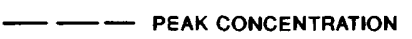

LEADING EDGE

Figure 5.--Cumulative traveltimes for the 1991 dye study.

\section{Discharge}

River discharges decreased from June 24 through July 3,1991. Discharge of the Kanawha River was measured at Kanawha Falls and Charleston (fig. 6). Daily mean discharge ranged from $5,540 \mathrm{ft}^{3} / \mathrm{s}$ on June 24 to $2,790 \mathrm{ft}^{3} / \mathrm{s}$ on July 2 at Kanawha Falls and from $5,680 \mathrm{ft}^{3} / \mathrm{s}$ on June 24 to $3,000 \mathrm{ft}^{3} / \mathrm{s}$ on July 2 at Charleston. Inflows to the Kanawha River were measured at Belva on the Gauley River, Queen Shoals on the Elk River, and Tornado on the Coal River (fig. 7). Daily mean discharge ranged from $208 \mathrm{ft}^{3} / \mathrm{s}$ to $132 \mathrm{ft}^{3} / \mathrm{s}$ at Belva, from $231 \mathrm{ft}^{3} / \mathrm{s}$ to $66 \mathrm{ft}^{3} / \mathrm{s}$ at
Queen Shoals, and from $376 \mathrm{ft}^{3} / \mathrm{s}$ to $131 \mathrm{ft}^{3} / \mathrm{s}$ at Tornado.

\section{Water-Surface Elevation}

Normal water-surface elevations for the navigable section of the Kanawha River are shown in figure 8. Water-surface elevations for the study period were approximately $1 \mathrm{ft}$ above normal downstream from Winfield Dam in the pool regulated by Gallipolis Dam on the Ohio River (fig. 9). Water-surface elevations were near normal for the Winfield pool (fig. 10), Marmet pool (fig. 11), and London pool (fig. 12). 
Table 4.--Location and additional information for selected streamflow-gaging stations

[mi, mile; $\mathrm{mi}^{2}$, square miles; $\mathrm{ft}$, feet; $\mathrm{RM}$, river mile; gage datum is the elevation of zero stage and is measured in feet above sea level; "Yes" indicates data are collected; "No" indicates data are not collected]

\begin{tabular}{|c|c|c|c|c|c|}
\hline $\begin{array}{l}\text { Streamflow- } \\
\text { gaging } \\
\text { station }\end{array}$ & Location & $\begin{array}{l}\text { Gage } \\
\text { datum }\end{array}$ & $\begin{array}{l}\text { Drainage } \\
\text { area } \\
\left(\mathrm{mi}^{2}\right)\end{array}$ & $\begin{array}{l}\text { Stage } \\
\text { data }\end{array}$ & $\begin{array}{l}\text { Discharge } \\
\text { data }\end{array}$ \\
\hline 03192000 & $\begin{array}{l}\text { Gauley River above Belva } \\
\text { ( } 6.3 \text { mi above mouth) }\end{array}$ & 669.00 & 1,317 & Yes & Yes \\
\hline 03193000 & $\begin{array}{l}\text { Kanawha River at Kanawha } \\
\text { Falls (at RM 94.3) }\end{array}$ & 621.20 & 8,371 & Yes & Yes \\
\hline 03193700 & $\begin{array}{l}\text { Kanawha River at London, } \\
\text { upstream of dam (at RM 82.8) }\end{array}$ & 600.15 & 8,493 & Yes & No \\
\hline 03193701 & $\begin{array}{l}\text { Kanawha River at London, } \\
\text { downstream of dam (at RM 82.8) }\end{array}$ & 580.19 & 8,493 & Yes & No \\
\hline 03193800 & $\begin{array}{l}\text { Kanawha River at Marmet, } \\
\text { upstream of dam (at RM 67.7) }\end{array}$ & 580.18 & 8,816 & Yes & No \\
\hline 03193805 & $\begin{array}{l}\text { Kanawha River at Marmet } \\
\text { downstream of dam (at RM 67.7) }\end{array}$ & 560.27 & 8,816 & Yes & No \\
\hline 03197000 & $\begin{array}{l}\text { Elk River at Queen Shoals } \\
\text { (26.2 mi above mouth) }\end{array}$ & 604.09 & 1,145 & Yes & Yes \\
\hline 03197990 & $\begin{array}{l}\text { Kanawha River at Charleston, } \\
\text { auxiliary gage (at RM 56.9) }\end{array}$ & 547.00 & 10,419 & Yes & No \\
\hline 03198000 & $\begin{array}{l}\text { Kanawha River at Charleston, } \\
\text { base gage (at RM 54.5) }\end{array}$ & 548.00 & 10,448 & Yes & Yes \\
\hline 03200500 & $\begin{array}{l}\text { Coal River at Tornado } \\
\text { (11.5 mi above mouth) }\end{array}$ & 570.46 & 862 & Yes & Yes \\
\hline 03201301 & $\begin{array}{l}\text { Kanawha River at Winfield, } \\
\text { upstream of dam (at RM 31.1) }\end{array}$ & 560.00 & 11,809 & Yes & No \\
\hline 03201305 & $\begin{array}{l}\text { Kanawha River at Winfield, } \\
\text { downstream of dam (at RM 31.1) }\end{array}$ & 530.00 & 11,809 & Yes & No \\
\hline 03201500 & $\begin{array}{l}\text { Ohio River at Point } \\
\text { Pleasant }(1,200 \mathrm{ft} \text { upstream } \\
\text { from confluence of Kanawha River) }\end{array}$ & 513.57 & ${ }^{1} 52,760$ & Yes & No \\
\hline
\end{tabular}

${ }^{1}$ Approximate drainage area, including that of the Kanawha River. 


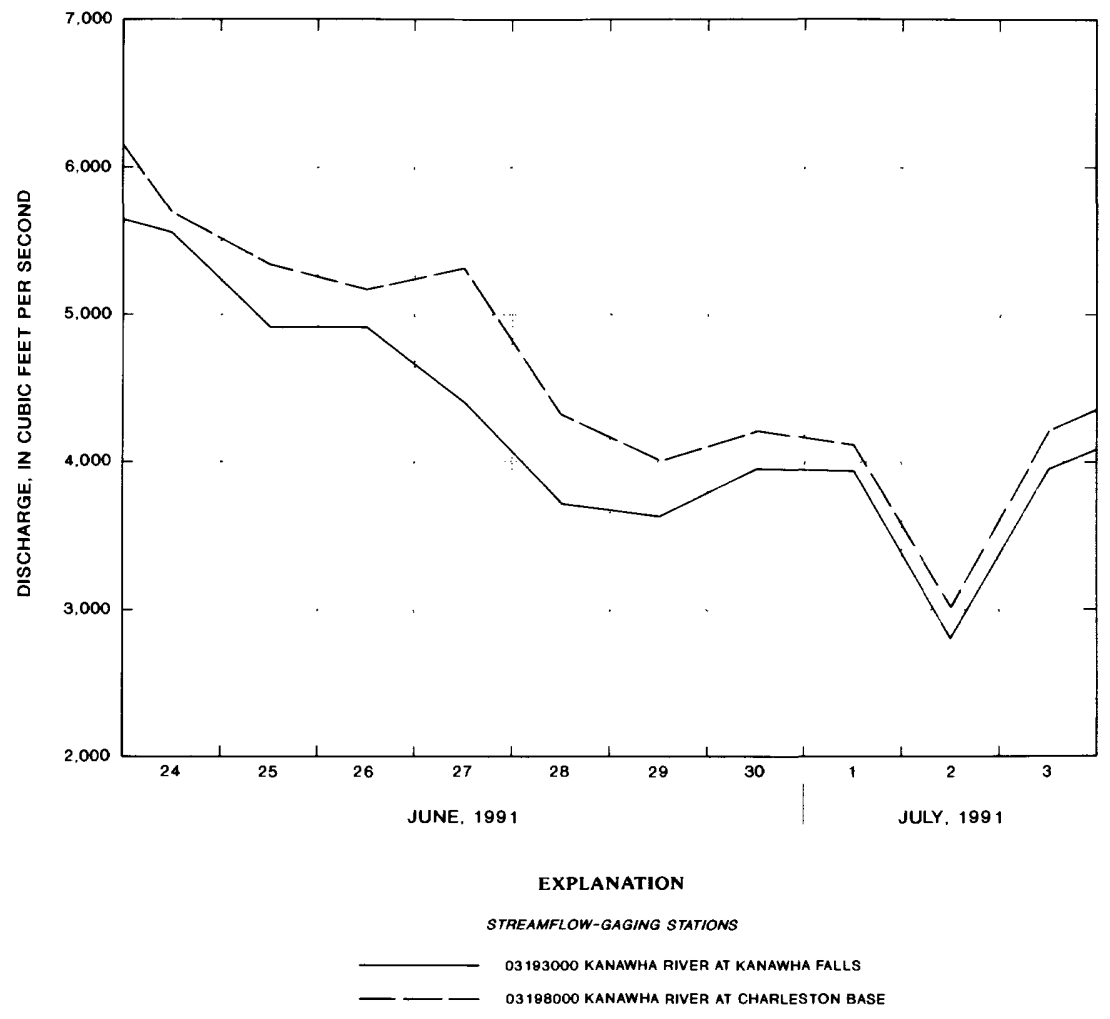

Figure 6.--Daily mean discharges for the Kanawha River at Kanawha Falls and Charleston, June 24 through July 3, 1991.

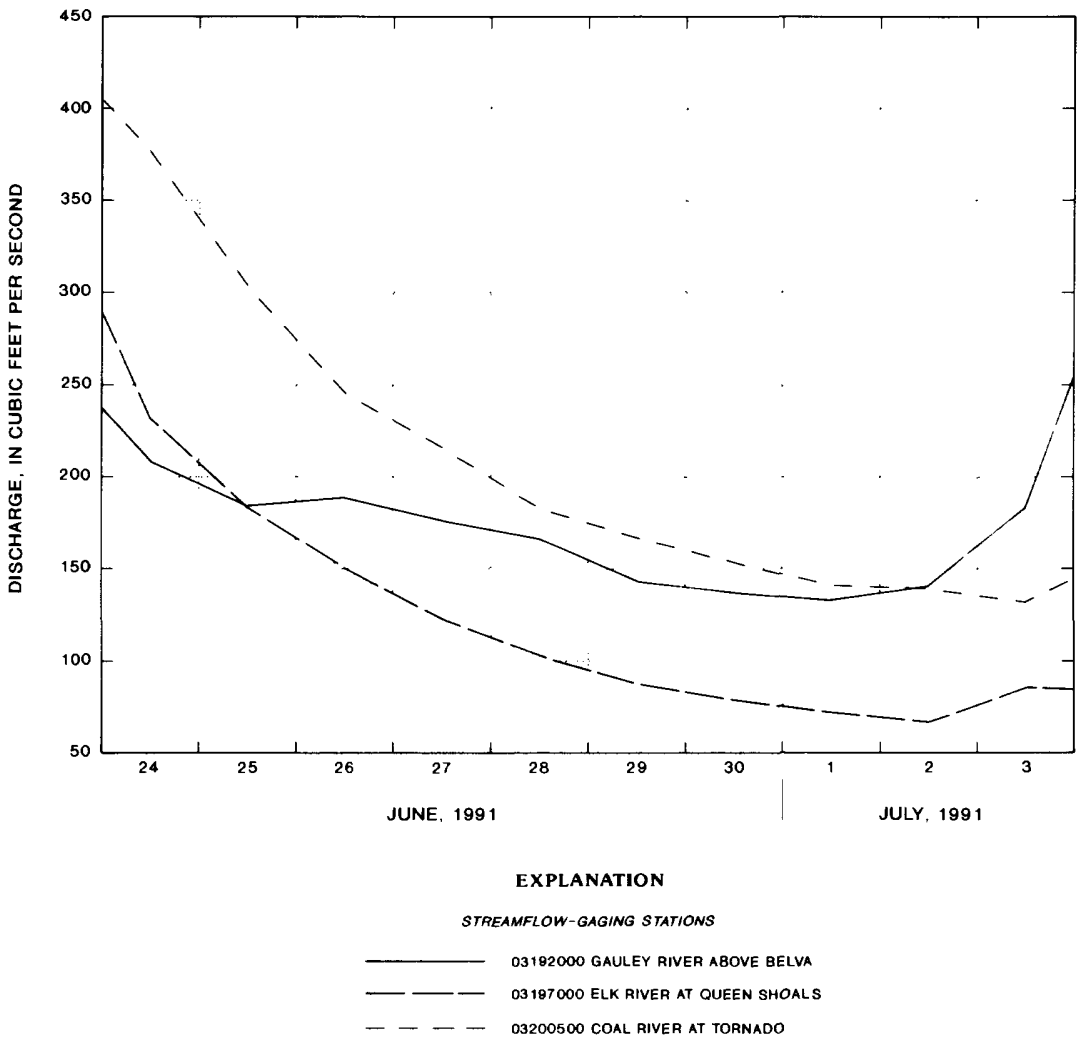

Figure 7.--Daily mean discharges for the Kanawha River from the Gauley, Elk, and Coal Rivers, June 24 through July 3, 1991. 


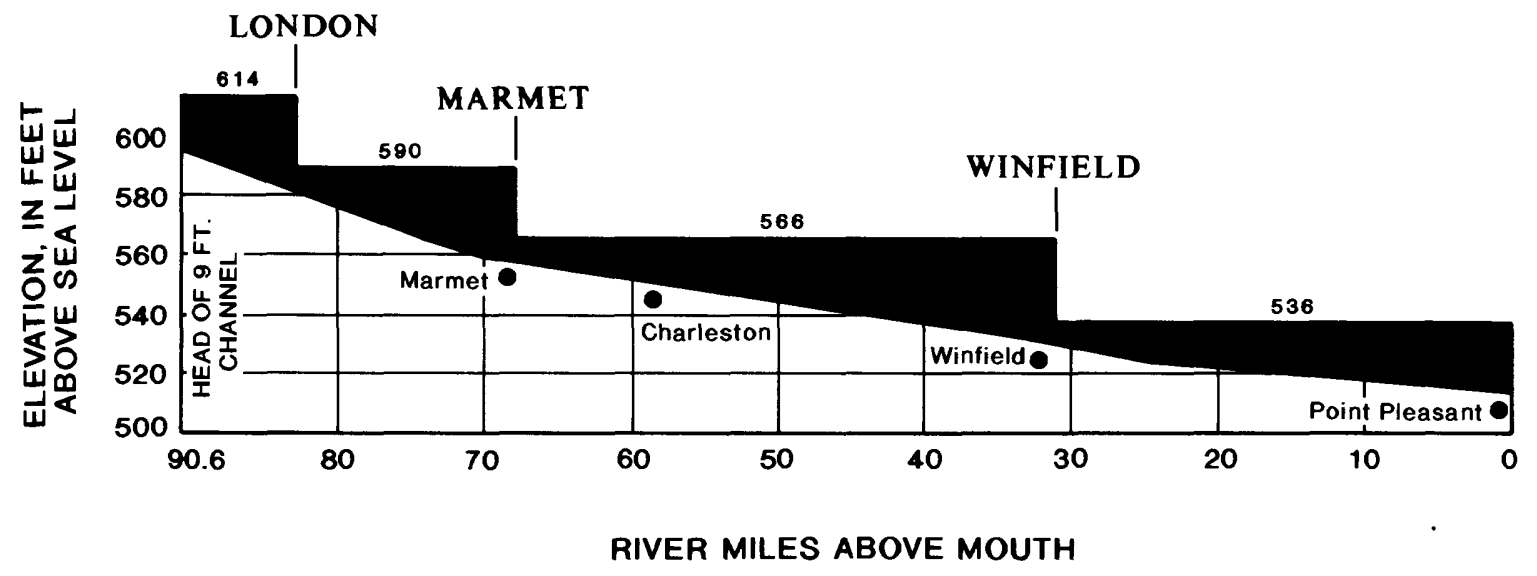

Figure 8.--Kanawha River profile, navigable section. (From Appel, 1991, p. 4)

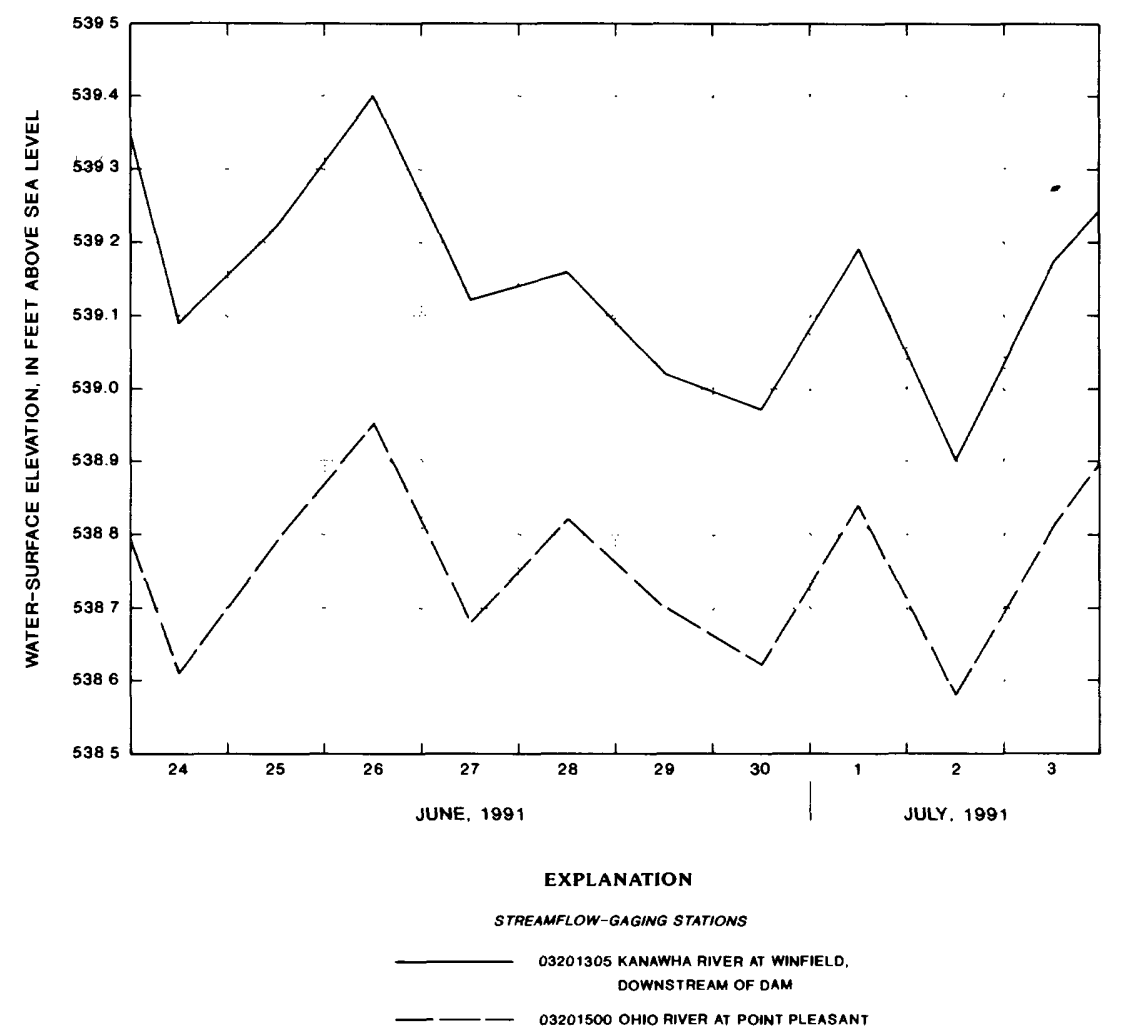

Figure 9--Daily mean water-surface elevations from June 24 through July 3, 1991, at Winfield and Point Pleasant in the Gallipolis pool. 


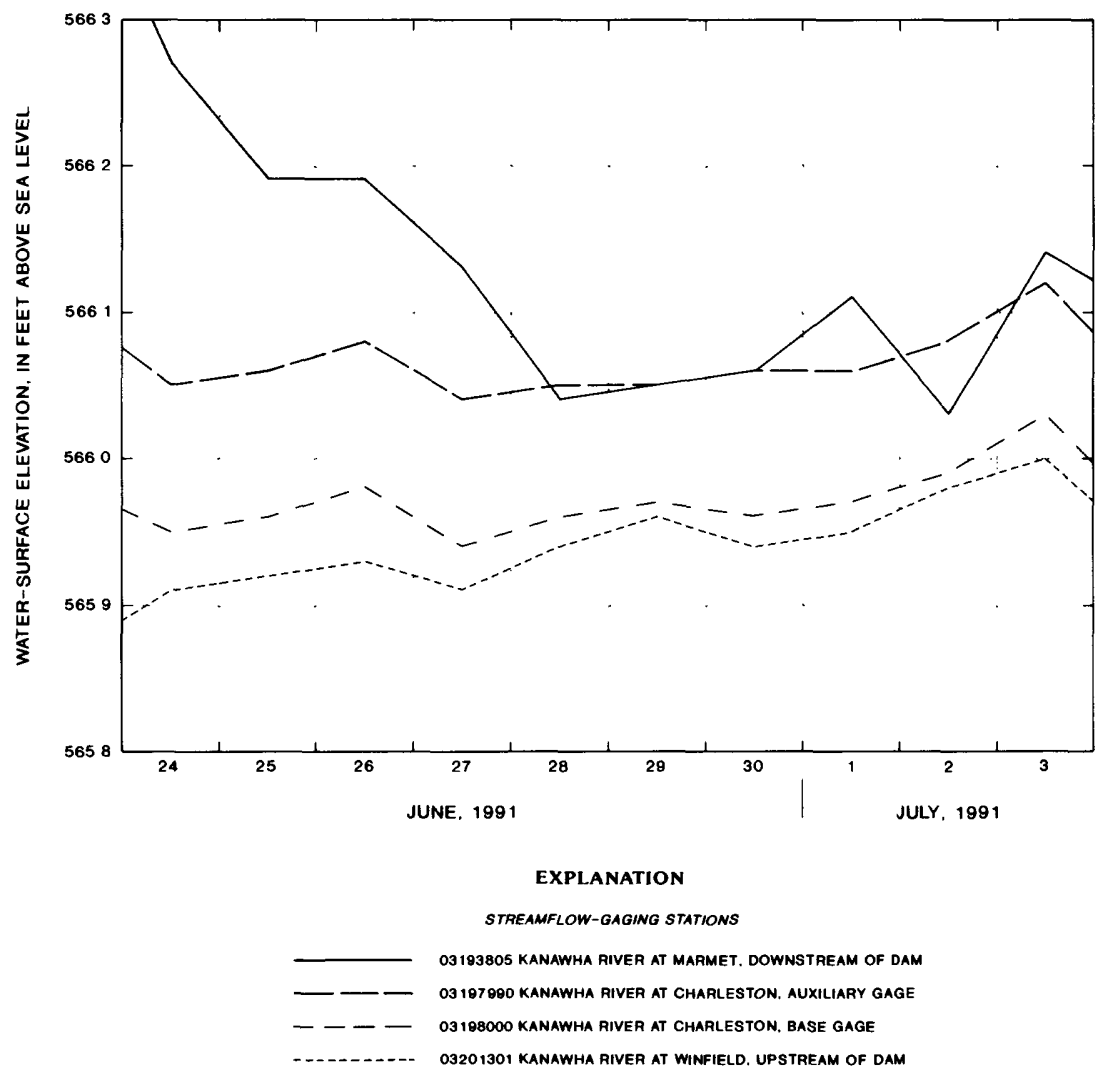

Figure 10.--Daily mean water-surface elevations from June 24 through July 3, 1991, at Winfield, Charleston, and Marmet in the Winfield pool.

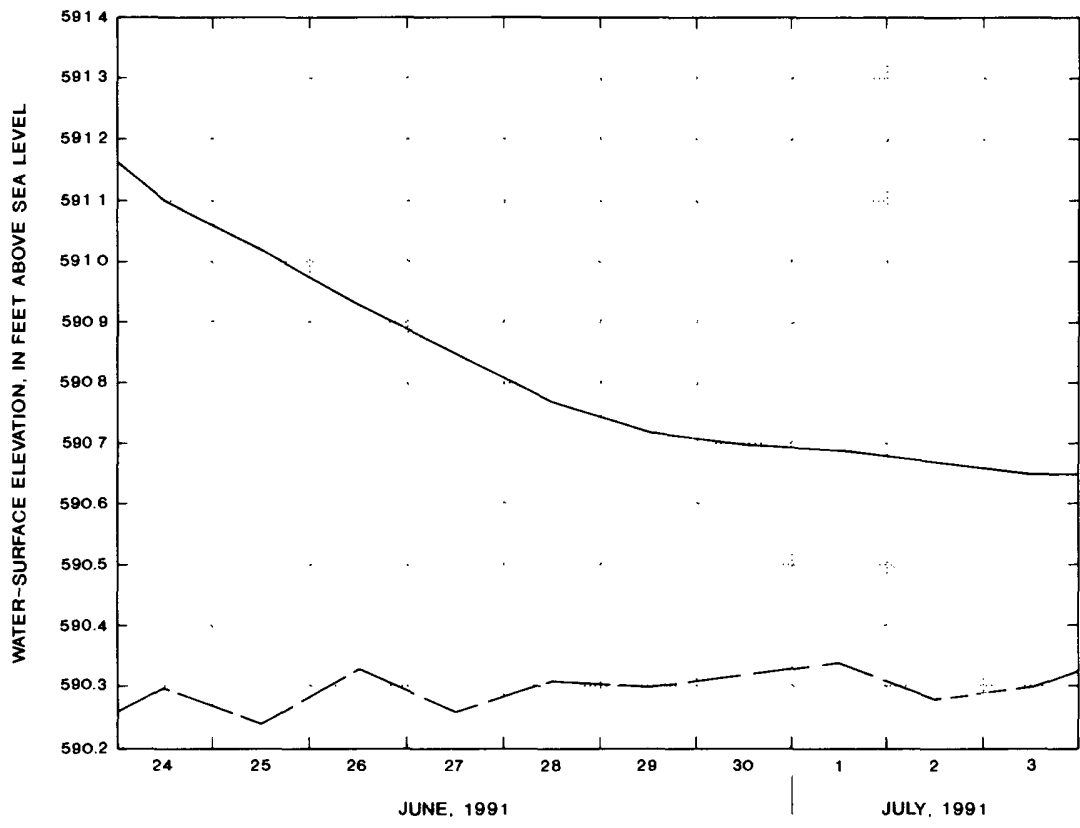

EXPLANATION

STREAMFLOW-GAGING STATIONS

O3 193701 KANAWHA RIVER AT LONDON. DOWNSTREAM OF DAM

O3193800 KANAWHA RIVER AT MARMET. UPSTAEAM OF DAM

Figure 11.--Daily mean water-surface elevations from June 24 through July 3, 1991, at Marmet and London in the Marmet pool. 


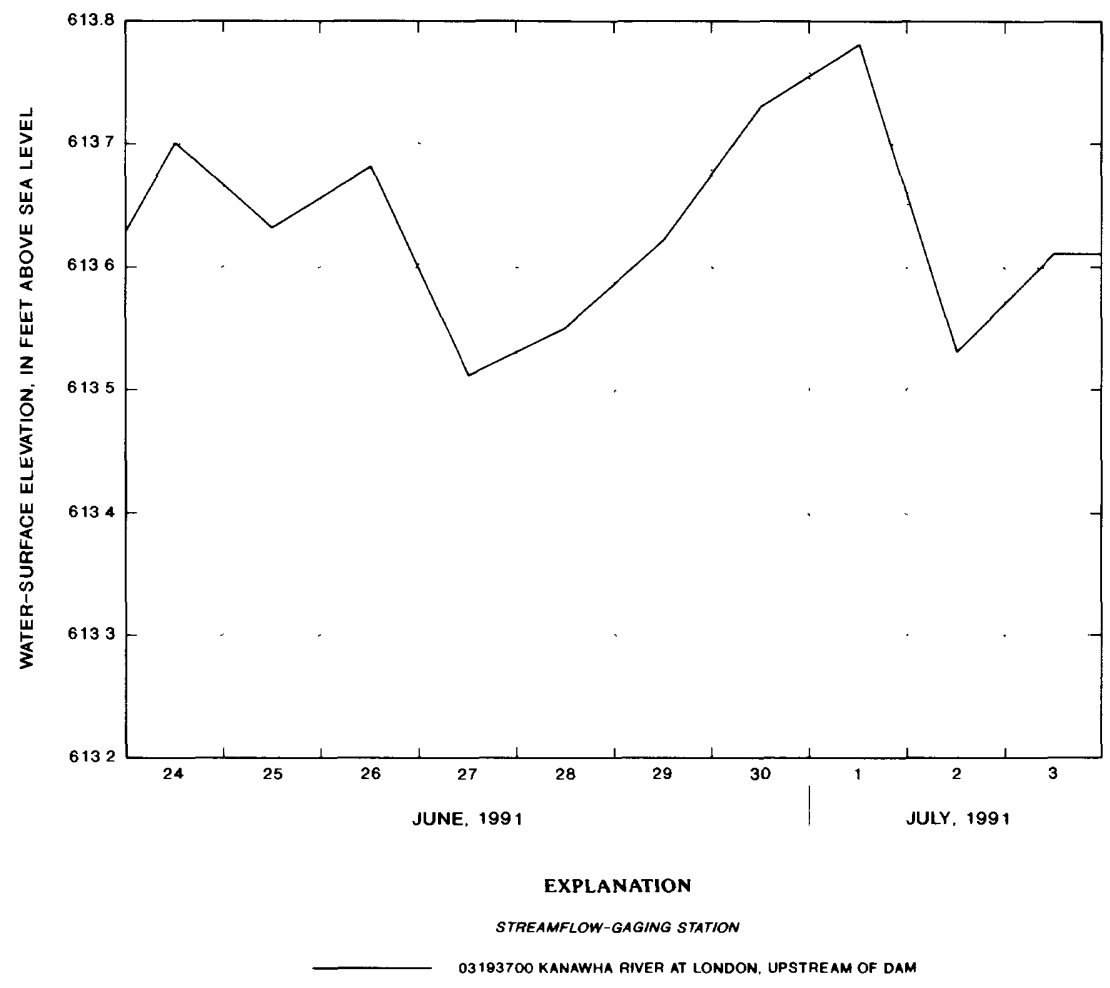

Figure 12.--Daily mean water-surface elevations from June 24 through July 3, 1991, at London in the London pool.

Between June 24 and July 3, 1991, a reduction of water storage in regulated pools occurred. This is indicated by the decline in water-surface elevations at upstream locations in the Gallipolis, Winfield, and Marmet pools, in comparison to the more stable water-surface elevations at the downstream locations in the pools (figs. 9-11).

\section{SUMMARY}

The Kanawha River originates in southcentral West Virginia and flows northwest to the Ohio River. The river is used for water supply, recreation, and transportation. Water quality of the river could be affected by an accidental spill of a soluble contaminant. Knowledge of estimated traveltimes and dispersion of solutes could help river managers to mitigate effects of such a spill. Traveltime and dispersion data were collected from June 24 through July 3, 1991. This data supplements data collected in August and October 1989.
Dye was injected at Hawks Nest Aqueduct, London Dam, and Marmet Dam. Water samples were collected at various river locations and analyzed for the presence of dye. Time-concentration curves were developed from this data and cumulative traveltimes were calculated (these curves and calculations should be used for making estimates only when river discharges are similar to this study). A spill of soluble material at Gauley Bridge under similar discharge conditions is estimated to take about 15 days to pass Winfield Dam. A spill is estimated to spend about 12 days in the Winfield pool. Estimated time of passage for this hypothetical spill is about 2.5 days at Marmet Dam and about 5.5 days at Winfield Dam.

River discharge decreased from June 24 through July 3, 1991. Daily mean discharges ranged from $5,540 \mathrm{ft}^{3} / \mathrm{s}$ to $2,790 \mathrm{ft}^{3} / \mathrm{s}$ at Kanawha Falls and from $5,680 \mathrm{ft}^{3} / \mathrm{s}$ to $3,000 \mathrm{ft}^{3} / \mathrm{s}$ at Charleston. 
Water-surface elevations were $1 \mathrm{ft}$ above normal in the Gallipolis pool, and were near normal in the Winfield, Marmet, and London pools. Changing water-surface elevations in the regulated pools indicated a loss of water storage during the study period.

\section{REFERENCES CITED}

Appel, D.H., 1991, Traveltime and dispersion data for the Kanawha River, West Virginia, 1989: U.S. Geological Survey Open-File Report 91-57, $16 \mathrm{p}$.

Cherniack, Martin, 1986, The Hawks Nest incident: New Haven, Conn., Yale University Press, $194 \mathrm{p}$.

Erwin, R.B., 1986, West Virginia gazetteer of physical and cultural place names, v. 24: West Virginia Geological and Economic Survey, $809 \mathrm{p}$.

Hubbard, E.F., Kilpatrick, F.A., Martens, L.A., and Wilson, Jr., J.F., 1982, Measurement of time of travel and dispersion in streams by dye tracing: U.S. Geological Survey Techniques of Water-Resources Investigations, book 3, chap. A9, $44 \mathrm{p}$.

Kilpatrick, F.A. and Wilson, J.F., Jr. 1989, Measurement of time of travel in streams by dye tracing: U.S. Geological Survey Techniques of Water-Resources Investigations, book 3, chap. A9, $27 \mathrm{p}$.

Mathes, M.V., Kirby, J.R., Payne, D.D., Jr., and Shultz, R.A., 1982, Drainage areas of the Kanawha River basin, West Virginia: U.S. Geological Survey Open-File Report 82-351, $222 \mathrm{p}$.
Rantz, S.E., and others, 1982, Measurement and computation of streamflow--Volume 1. Measurement of stage and discharge; Volume 2. Computation of discharge: U.S. Geological Survey Water-Supply Paper 2175, 631 p.

U.S. Army Corps of Engineers, 1989, Navigation charts for the Kanawha River: U.S. Army Corps of Engineers, Ohio River Division, Huntington District, charts 1-19. 1990, Navigation charts for the Ohio River: U.S. Army Corps of Engineers, Ohio River Division, Huntington District, charts 108-172.

Wilson, J.F., Jr., Cobb, E.D., and Kilpatrick, F.A., 1986, Fluorometric procedures for dye tracing: U.S. Geological Survey Techniques of Water Resources Investigations, book 3, chap. A12, 34 p. 
Table 5.--Unit times and concentrations at the indicated locations for the dye injection at Hawks Nest Dam, through Hawks Nest Aqueduct

[Time is military time. Elapsed time is in percentage of hours since injection. Concentration is in micrograms per liter]

\begin{tabular}{lccccccc}
\hline Date & Time & $\begin{array}{c}\text { Elapsed } \\
\text { time }\end{array}$ & Concentration & Date & Time & $\begin{array}{c}\text { Elapsed } \\
\text { time }\end{array}$ & Concentration \\
\hline \multicolumn{7}{c}{ Gauley } & Bridge, railroad bridge over New River \\
$6-25-91$ & 1200 & 0.00 & 0.05 & $6-25-91$ & 1335 & 1.58 & 10.25 \\
& 1205 & .08 & .05 & & 1340 & 1.67 & 4.68 \\
& 1210 & .17 & .05 & 1345 & 1.75 & 2.45 \\
1220 & .33 & .05 & 1351 & 1.85 & 1.34 \\
& 1230 & .50 & .05 & 1355 & 1.92 & 1.81 \\
& & & & & & \\
& 1240 & .67 & .05 & 1400 & 2.00 & 1.20 \\
1250 & .83 & .05 & 1410 & 2.17 & .56 \\
1300 & 1.00 & .05 & 1420 & 2.33 & .42 \\
1305 & 1.08 & .05 & 1430 & 2.50 & .28 \\
1310 & 1.17 & .05 & & & .14 \\
& & & & 1445 & 2.75 & \\
& 1315 & 1.25 & 15.30 & 1500 & 3.00 & .09 \\
1320 & 1.33 & 90.47 & 1515 & 3.25 & .05 \\
1325 & 1.42 & 70.34 & 1600 & 4.50 & .05 \\
1330 & 1.50 & 27.71 & & & .05
\end{tabular}

\begin{tabular}{|c|c|c|c|c|c|c|c|}
\hline $6-25-91$ & 1700 & 5.00 & 0.05 & $6-26-91$ & 0045 & 12.75 & 1.67 \\
\hline & 1800 & 6.00 & .14 & & 0100 & 13.00 & 2.22 \\
\hline & 1845 & 6.75 & .05 & & 0115 & 13.25 & 1.25 \\
\hline & 1915 & 7.25 & .23 & & 0130 & 13.50 & 2.13 \\
\hline & 2000 & 8.00 & .09 & & 0145 & 13.75 & 1.30 \\
\hline & 2015 & 8.25 & .23 & & 0200 & 14.00 & 1.16 \\
\hline & 2030 & 8.50 & .46 & & 0215 & 14.25 & 1.57 \\
\hline & 2045 & 8.75 & .56 & & 0230 & 14.50 & .97 \\
\hline & 2100 & 9.00 & 1.48 & & 0245 & 14.75 & 1.34 \\
\hline & 2115 & 9.25 & 1.67 & & 0300 & 15.00 & 1.20 \\
\hline & 2130 & 9.50 & 2.08 & & 0315 & 15.25 & 1.02 \\
\hline & 2145 & 9.75 & 2.36 & & 0330 & 15.50 & .88 \\
\hline & 2200 & 10.00 & 2.32 & & 0345 & 15.75 & .83 \\
\hline & 2215 & 10.25 & 2.92 & & 0400 & 16.00 & .65 \\
\hline & 2230 & 10.50 & 3.43 & & 0415 & 16.25 & .60 \\
\hline & 2245 & 10.75 & 3.38 & & 0430 & 16.50 & .56 \\
\hline & 2300 & 11.00 & 3.89 & & 0445 & 16.75 & .51 \\
\hline & 2315 & 11.25 & 3.06 & & 0500 & 17.00 & .46 \\
\hline & 2345 & 11.75 & 3.75 & & 0520 & 17.33 & .42 \\
\hline & 2400 & 12.00 & 3.57 & & 0540 & 17.67 & .42 \\
\hline $6-26-91$ & 0015 & 12.25 & 2.22 & & 0600 & 18.00 & .37 \\
\hline & 0030 & 12.50 & 2.87 & & & & \\
\hline
\end{tabular}


Table 5.--Unit times and concentrations at the indicated locations for the dye injection at Hawks Nest Dam, through Hawks Nest Aqueduct-Continued

[Time is military time. Elapsed time is in percentage of hours since injection. Concentration is in micrograms per liter]

\begin{tabular}{|c|c|c|c|c|c|c|c|}
\hline Date & Time & $\begin{array}{c}\text { Elapsed } \\
\text { time }\end{array}$ & Concentration & Date & Time & $\begin{array}{c}\text { Elapsed } \\
\text { time }\end{array}$ & Concentration \\
\hline \multicolumn{8}{|c|}{ Deepwater, railroad bridge } \\
\hline $6-25-91$ & 2400 & 12.00 & 0.09 & $6-26-91$ & 0620 & 18.33 & 2.08 \\
\hline \multirow[t]{18}{*}{$6-26-91$} & 0020 & 12.33 & .32 & & 0640 & 18.67 & 1.90 \\
\hline & 0040 & 12.67 & .60 & & 0700 & 19.00 & 1.67 \\
\hline & 0100 & 13.00 & .83 & & 0720 & 19.33 & 1.53 \\
\hline & 0120 & 13.33 & 1.16 & & 0740 & 19.67 & 1.32 \\
\hline & 0140 & 13.67 & 2.18 & & 0800 & 20.00 & 1.16 \\
\hline & 0200 & 14.00 & 2.32 & & 0820 & 20.33 & 1.11 \\
\hline & 0220 & 14.33 & 2.50 & & 0840 & 20.67 & 1.02 \\
\hline & 0240 & 14.67 & 2.87 & & 0900 & 21.00 & .83 \\
\hline & 0300 & 15.00 & 3.10 & & 0920 & 21.33 & .74 \\
\hline & 0320 & 15.33 & 3.15 & & 0940 & 21.67 & .69 \\
\hline & 0340 & 15.67 & 3.24 & & 1000 & 22.00 & .65 \\
\hline & 0400 & 16.00 & 3.29 & & 1020 & 22.33 & .51 \\
\hline & 0420 & 16.33 & 3.15 & & 1040 & 22.67 & .46 \\
\hline & 0440 & 16.67 & 2.96 & & 1200 & 24.00 & .32 \\
\hline & 0500 & 17.00 & 2.78 & & 1220 & 24.33 & .23 \\
\hline & 0520 & 17.33 & 2.64 & & 1240 & 24.67 & .23 \\
\hline & 0540 & 17.67 & 2.50 & & 1300 & 25.00 & .14 \\
\hline & 0600 & 18.00 & 2.22 & & & & \\
\hline \multicolumn{8}{|c|}{ London Dam } \\
\hline \multirow[t]{7}{*}{$6-26-91$} & 1200 & 24.00 & 0.09 & $6-27-91$ & 0925 & 45.42 & 0.97 \\
\hline & 1945 & 31.75 & .00 & & 1019 & 46.32 & 1.02 \\
\hline & 2000 & 32.00 & .05 & & 1113 & 47.21 & 1.02 \\
\hline & 2053 & 32.89 & .09 & & 1206 & 48.10 & 1.48 \\
\hline & 2147 & 33.78 & .05 & & 1300 & 49.00 & 1.48 \\
\hline & 2241 & 34.68 & .05 & & 1353 & 49.89 & 1.57 \\
\hline & 2335 & 35.58 & .09 & & 1447 & 50.79 & 1.39 \\
\hline \multirow[t]{8}{*}{$6-27-91$} & 0028 & 36.47 & .14 & & 1541 & 51.68 & 1.11 \\
\hline & 0216 & 38.26 & .14 & & 1600 & 52.00 & 1.16 \\
\hline & 0310 & 39.16 & .19 & & 1654 & 52.90 & .88 \\
\hline & 0457 & 40.95 & .32 & & 1759 & 53.81 & .69 \\
\hline & 0550 & 41.84 & .42 & & 1853 & 54.71 & .69 \\
\hline & 0644 & 42.74 & .46 & & 1937 & 55.62 & .56 \\
\hline & 0738 & 43.63 & .74 & & 2031 & 56.52 & .56 \\
\hline & 0832 & 44.53 & .76 & & 2126 & 57.43 & .46 \\
\hline
\end{tabular}


Table 5.--Unit times and concentrations at the indicated locations for the dye injection at Hawks Nest Dam, through Hawks Nest Aqueduct--Continued

[Time is military time. Elapsed time is in percentage of hours since injection. Concentration is in micrograms per liter]

\begin{tabular}{|c|c|c|c|c|c|c|c|}
\hline Date & Time & $\begin{array}{l}\text { Elapsed } \\
\text { time }\end{array}$ & Concentration & Date & Time & $\begin{array}{c}\text { Elapsed } \\
\text { time }\end{array}$ & Concentration \\
\hline \multicolumn{8}{|c|}{ London Dam-Continued } \\
\hline \multirow[t]{2}{*}{$6-27-91$} & 2220 & 58.33 & 0.42 & $6-28-91$ & 0441 & 64.69 & 0.19 \\
\hline & 2314 & 59.24 & .42 & & 0534 & 65.57 & .14 \\
\hline \multirow[t]{5}{*}{$6-28-91$} & 0008 & 60.14 & .37 & & 0629 & 66.48 & .14 \\
\hline & 0103 & 61.05 & .37 & & 0723 & 67.38 & .14 \\
\hline & 0157 & 61.95 & .32 & & 1006 & 70.10 & .14 \\
\hline & 0252 & 62.86 & .23 & & 1100 & 71.00 & .14 \\
\hline & 0346 & 63.76 & .19 & & & & \\
\hline \multicolumn{8}{|c|}{ Chelyan, Highway 61 bridge } \\
\hline \multirow[t]{20}{*}{$6-28-91$} & 0630 & 66.50 & 0.09 & $6-28-91$ & 1900 & 79.00 & 0.69 \\
\hline & 0700 & 67.00 & .09 & & 2000 & 80.00 & .79 \\
\hline & 0730 & 67.50 & .09 & & 2100 & 81.00 & .93 \\
\hline & 0800 & 68.00 & .09 & & 2200 & 82.00 & .97 \\
\hline & 0830 & 68.50 & .09 & & 2300 & 83.00 & .97 \\
\hline & 0900 & 69.00 & .09 & $6-29-91$ & 0100 & 85.00 & 1.11 \\
\hline & 0930 & 69.50 & .19 & & 0700 & 91.00 & .83 \\
\hline & 1000 & 70.00 & .14 & & 0800 & 92.00 & .74 \\
\hline & 1030 & 70.50 & .14 & & 0900 & 93.00 & .74 \\
\hline & 1100 & 71.00 & .14 & & 1000 & 94.00 & .74 \\
\hline & 1130 & 71.50 & .14 & & 1100 & 95.00 & .56 \\
\hline & 1200 & 72.00 & .19 & & 1200 & 96.00 & .46 \\
\hline & 1230 & 72.50 & .19 & & 1600 & 100.00 & .37 \\
\hline & 1300 & 73.00 & .23 & & 1700 & 101.00 & .32 \\
\hline & 1330 & 73.50 & .28 & & 1800 & 102.00 & .32 \\
\hline & 1400 & 74.00 & .28 & & 1900 & 103.00 & .28 \\
\hline & 1500 & 75.00 & .37 & & 2000 & 104.00 & .19 \\
\hline & 1600 & 76.00 & .42 & & 2100 & 105.00 & .19 \\
\hline & 1700 & 77.00 & .51 & & 2200 & 106.00 & .23 \\
\hline & 1800 & 78.00 & .65 & & & & \\
\hline
\end{tabular}


Table 6.--Unit times and concentrations at the indicated locations for the dye injection at London Dam

[Time is military time. Elapsed time is in percentage of hours since injection. Concentration is in micrograms per liter]

\begin{tabular}{|c|c|c|c|c|c|c|c|}
\hline Date & Time & $\begin{array}{c}\text { Elapsed } \\
\text { time }\end{array}$ & Concentration & Date & Time & $\begin{array}{c}\text { Elapsed } \\
\text { time }\end{array}$ & Concentration \\
\hline \multicolumn{8}{|c|}{ Chelyan, Highway 61 bridge } \\
\hline \multirow{30}{*}{$6-25-91$} & 0603 & 12.05 & 0.05 & $6-25-91$ & 2045 & 26.75 & 1.39 \\
\hline & 1333 & 19.55 & .05 & & 2100 & 27.00 & 1.39 \\
\hline & 1345 & 19.75 & .05 & & 2115 & 27.25 & 1.30 \\
\hline & 1400 & 20.00 & .05 & & 2130 & 27.50 & 1.11 \\
\hline & 1415 & 20.25 & .05 & & 2145 & 27.75 & 1.16 \\
\hline & 1430 & 20.50 & .05 & & 2200 & 28.00 & 1.11 \\
\hline & 1445 & 20.75 & .09 & & 2215 & 28.25 & 1.06 \\
\hline & 1500 & 21.00 & .23 & & 2230 & 28.50 & .60 \\
\hline & 1515 & 21.25 & .14 & & 2245 & 28.75 & 1.02 \\
\hline & 1530 & 21.50 & .46 & & 2300 & 29.00 & .56 \\
\hline & 1545 & 21.75 & .46 & & 2315 & 29.25 & .83 \\
\hline & 1600 & 22.00 & .83 & & 2330 & 29.50 & .74 \\
\hline & 1615 & 22.25 & .97 & & 2345 & 29.75 & .37 \\
\hline & 1630 & 22.50 & 1.30 & & 2400 & 30.00 & .83 \\
\hline & 1645 & 22.75 & .93 & $6-26-91$ & 0015 & 30.25 & .56 \\
\hline & 1700 & 23.00 & 1.11 & & 0030 & 30.50 & .69 \\
\hline & 1715 & 23.25 & 1.99 & & 0045 & 30.75 & .46 \\
\hline & 1730 & 23.50 & 1.85 & & 0100 & 31.00 & .42 \\
\hline & 1745 & 23.75 & 1.94 & & 0115 & 31.25 & .42 \\
\hline & 1800 & 24.00 & .97 & & 0130 & 31.50 & .28 \\
\hline & 1815 & 24.25 & 1.76 & & 0145 & 31.75 & .28 \\
\hline & 1830 & 24.50 & 1.76 & & 0200 & 32.00 & .28 \\
\hline & 1845 & 24.75 & 1.90 & & 0215 & 32.25 & .19 \\
\hline & 1900 & 25.00 & 1.67 & & 0230 & 32.50 & .23 \\
\hline & 1915 & 25.25 & 1.48 & & 0245 & 32.75 & .28 \\
\hline & 1930 & 25.50 & 1.48 & & 0300 & 33.00 & .19 \\
\hline & 1945 & 25.75 & 1.62 & & 0315 & 33.25 & .14 \\
\hline & 2000 & 26.00 & 1.62 & & 0330 & 33.50 & .28 \\
\hline & 2015 & 26.25 & 1.67 & & 0345 & 33.75 & .09 \\
\hline & 2030 & 26.50 & 1.30 & & 0400 & 34.00 & .14 \\
\hline \multicolumn{8}{|c|}{ Marmet Dam } \\
\hline \multirow[t]{5}{*}{$6-26-91$} & 1003 & 40.05 & 0.05 & $6-26-91$ & 1445 & 44.75 & 0.05 \\
\hline & 1258 & 42.97 & .05 & & 1512 & 45.20 & .09 \\
\hline & 1325 & 43.42 & .05 & & 1538 & 45.64 & .18 \\
\hline & 1352 & 43.86 & .05 & & 1605 & 46.09 & .23 \\
\hline & 1419 & 44.31 & .05 & & 1632 & 46.53 & .23 \\
\hline
\end{tabular}


Table 6.--Unit times and concentrations at the indicated locations for the dye injection at London Dam--Continued

[Time is military time. Elapsed time is in percentage of hours since injection. Concentration is in micrograms per liter]

\begin{tabular}{|c|c|c|c|c|c|c|c|}
\hline Date & Time & $\begin{array}{c}\text { Elapsed } \\
\text { time }\end{array}$ & Concentration & Date & Time & $\begin{array}{c}\text { Elapsed } \\
\text { time }\end{array}$ & Concentration \\
\hline \multicolumn{8}{|c|}{ Marmet Dam-Continued } \\
\hline \multirow{9}{*}{$6-26-91$} & 1659 & 46.98 & 0.28 & $6-27-91$ & 1100 & 65.00 & 0.37 \\
\hline & 1725 & 47.42 & .32 & & 1200 & 66.00 & .32 \\
\hline & 1800 & 48.00 & .37 & & 1300 & 67.00 & .28 \\
\hline & 1900 & 49.00 & .32 & & 1400 & 68.00 & .19 \\
\hline & 2000 & 50.00 & .74 & & 1415 & 68.25 & .19 \\
\hline & 2100 & 51.00 & .93 & & 1515 & 69.25 & .19 \\
\hline & 2200 & 52.00 & 1.02 & & 1615 & 70.25 & .19 \\
\hline & 2300 & 53.00 & 1.06 & & 1715 & 71.25 & .14 \\
\hline & 2400 & 54.00 & 1.02 & & 1815 & 72.25 & .09 \\
\hline \multirow[t]{11}{*}{$6-27-91$} & 0100 & 55.00 & 1.11 & & 1915 & 73.25 & .09 \\
\hline & 0200 & 56.00 & 1.11 & & 2015 & 74.25 & .09 \\
\hline & 0300 & 57.00 & 1.02 & & 2115 & 75.25 & .09 \\
\hline & 0400 & 58.00 & 1.06 & & 2215 & 76.25 & .05 \\
\hline & 0500 & 59.00 & 1.02 & & 2315 & 77.25 & .09 \\
\hline & 0600 & 60.00 & .88 & $6-28-91$ & 0815 & 86.25 & .05 \\
\hline & 0700 & 61.00 & .79 & & 0915 & 87.25 & .05 \\
\hline & 0800 & 62.00 & .56 & & & & \\
\hline & 0900 & 63.00 & .56 & & & & \\
\hline & 1000 & 64.00 & .42 & & & & \\
\hline & \multicolumn{7}{|c|}{ Charleston, 35th Street bridge } \\
\hline $6-26-91$ & 1800 & 48.00 & 0.05 & $6-27-91$ & 1000 & 64.00 & 0.52 \\
\hline \multirow[t]{16}{*}{$6-27-91$} & 0200 & 56.00 & .05 & & 1100 & 65.00 & .57 \\
\hline & 0230 & 56.50 & .05 & & 1130 & 65.50 & .71 \\
\hline & 0300 & 57.00 & .05 & & 1200 & 66.00 & .76 \\
\hline & 0330 & 57.50 & .05 & & 1330 & 67.50 & .86 \\
\hline & 0400 & 58.00 & .10 & & 1430 & 68.50 & 1.00 \\
\hline & 0430 & 58.50 & .10 & & 1500 & 69.00 & 1.05 \\
\hline & 0500 & 59.00 & .14 & & 1600 & 70.00 & 1.00 \\
\hline & 0530 & 59.50 & .19 & & 1630 & 70.50 & 1.00 \\
\hline & 0600 & 60.00 & .14 & & 1700 & 71.00 & 1.05 \\
\hline & 0630 & 60.50 & .24 & & 1730 & 71.50 & 1.05 \\
\hline & 0700 & 61.00 & .24 & & 1800 & 72.00 & 1.00 \\
\hline & 0730 & 61.50 & .29 & & 1830 & 72.50 & 1.00 \\
\hline & 0800 & 62.00 & .29 & & 1900 & 73.00 & 1.00 \\
\hline & 0830 & 62.50 & .38 & & 1930 & 73.50 & .90 \\
\hline & 0900 & 63.00 & .48 & & 2000 & 74.00 & .86 \\
\hline & 0930 & 63.50 & .52 & & 2030 & 74.50 & .81 \\
\hline
\end{tabular}


Table 6.--Unit times and concentrations at the indicated locations for the dye injection at London Dam-Continued

[Time is military time. Elapsed time is in percentage of hours since injection. Concentration is in micrograms per liter]

\begin{tabular}{|c|c|c|c|c|c|c|c|}
\hline Date & Time & $\underset{\text { time }}{\text { Elapsed }}$ & Concentration & Date & Time & $\begin{array}{c}\text { Elapsed } \\
\text { time }\end{array}$ & Concentration \\
\hline & \multicolumn{7}{|c|}{ Charleston, 35th Street bridge--Continued } \\
\hline \multirow[t]{6}{*}{$6-27-91$} & 2100 & 75.00 & 0.76 & $6-28-91$ & 0300 & 81.00 & 0.38 \\
\hline & 2130 & 75.50 & .67 & & 0400 & 82.00 & .29 \\
\hline & 2200 & 76.00 & .71 & & 0500 & 83.00 & .33 \\
\hline & 2230 & 76.50 & .67 & & 0600 & 84.00 & .29 \\
\hline & 2300 & 77.00 & .62 & & 0700 & 85.00 & .24 \\
\hline & 2400 & 78.00 & .57 & & 0800 & 86.00 & .19 \\
\hline \multirow[t]{4}{*}{$6-28-91$} & 0030 & 78.50 & .57 & & 0900 & 87.00 & .14 \\
\hline & 0100 & 79.00 & .57 & & 1000 & 88.00 & .14 \\
\hline & 0130 & 79.50 & .52 & & 1200 & 90.00 & .10 \\
\hline & 0200 & 80.00 & .43 & & 1500 & 93.00 & .10 \\
\hline
\end{tabular}


Table 7.--Unit times and concentrations at the indicated locations for the dye injection at Marmet Dam

[Time is military time. Elapsed time is in percentage of hours since injection. Concentration is in micrograms per liter]

\begin{tabular}{|c|c|c|c|c|c|c|c|}
\hline Date & Time & $\underset{\text { time }}{\text { Elapsed }}$ & Concentration & Date & Time & $\begin{array}{c}\text { Elapsed } \\
\text { time }\end{array}$ & Concentration \\
\hline \multicolumn{8}{|c|}{ Charleston, 35th Street bridge } \\
\hline \multirow[t]{17}{*}{ 6-24-91 } & 1620 & 9.33 & 0.05 & $6-24-91$ & 1930 & 12.50 & 4.09 \\
\hline & 1630 & 9.50 & .05 & & 1940 & 12.67 & 4.62 \\
\hline & 1640 & 9.67 & .10 & & 1950 & 12.83 & 2.71 \\
\hline & 1650 & 9.83 & .14 & & 2000 & 13.00 & 2.76 \\
\hline & 1700 & 10.00 & .81 & & 2030 & 13.50 & 1.90 \\
\hline & 1710 & 10.17 & 3.05 & & 2045 & 13.75 & .71 \\
\hline & 1720 & 10.33 & 8.26 & & 2100 & 14.00 & .57 \\
\hline & 1730 & 10.50 & 7.96 & & 2115 & 14.25 & .52 \\
\hline & 1740 & 10.67 & 7.96 & & 2130 & 14.50 & .67 \\
\hline & 1745 & 10.75 & 12.70 & & 2145 & 14.75 & 1.14 \\
\hline & 1750 & 10.83 & 15.15 & & 2200 & 15.00 & .95 \\
\hline & 1820 & 11.33 & 14.23 & & 2215 & 15.25 & .71 \\
\hline & 1830 & 11.50 & 14.08 & & 2230 & 15.50 & .67 \\
\hline & 1840 & 11.67 & 8.72 & & 2300 & 16.00 & .52 \\
\hline & 1850 & 11.83 & 8.87 & & 2315 & 16.25 & .33 \\
\hline & 1910 & 12.17 & 5.36 & & 2330 & 16.50 & .38 \\
\hline & 1920 & 12.33 & 3.38 & & & & \\
\hline \multicolumn{8}{|c|}{ Charleston, Patrick Street bridge } \\
\hline $6-24-91$ & 1100 & 4.00 & 0.05 & $6-25-91$ & 0515 & 22.25 & 7.34 \\
\hline & 2140 & 14.67 & .05 & & 0530 & 22.50 & 6.27 \\
\hline & 2200 & 15.00 & .00 & & 0600 & 23.00 & 2.50 \\
\hline & 2215 & 15.25 & .05 & & 0615 & 23.25 & 3.98 \\
\hline \multirow[t]{13}{*}{$6-25-91$} & 0200 & 19.00 & .00 & & 0630 & 23.50 & 4.58 \\
\hline & 0215 & 19.25 & .05 & & 0645 & 23.75 & 3.70 \\
\hline & 0230 & 19.50 & .09 & & 0700 & 24.00 & 2.08 \\
\hline & 0245 & 19.75 & .19 & & 0715 & 24.25 & 3.19 \\
\hline & 0300 & 20.00 & .28 & & 0730 & 24.50 & 2.55 \\
\hline & 0315 & 20.25 & 1.48 & & 0745 & 24.75 & 2.59 \\
\hline & 0330 & 20.50 & 2.36 & & 0800 & 25.00 & 1.76 \\
\hline & 0345 & 20.75 & 3.52 & & 0815 & 25.25 & 2.55 \\
\hline & 0400 & 21.00 & 4.63 & & 0830 & 25.50 & 2.32 \\
\hline & 0415 & 21.25 & 6.27 & & 0845 & 25.75 & 1.99 \\
\hline & 0430 & 21.50 & 7.04 & & 0900 & 26.00 & 1.81 \\
\hline & 0445 & 21.75 & 5.51 & & 0915 & 26.25 & 1.76 \\
\hline & 0500 & 22.00 & 5.51 & & 0930 & 26.50 & 1.85 \\
\hline
\end{tabular}


Table 7.--Unit times and concentrations at the indicated locations for the dye injection at Marmet Dam--Continued

[Time is military time. Elapsed time is in percentage of hours since injection. Concentration is in micrograms per liter]

\begin{tabular}{|c|c|c|c|c|c|c|c|}
\hline Date & Time & $\begin{array}{c}\text { Elapsed } \\
\text { time }\end{array}$ & Concentration & Date & Time & $\begin{array}{c}\text { Elapsed } \\
\text { time }\end{array}$ & Concentration \\
\hline \multicolumn{8}{|c|}{ Charleston, Patrick Street bridge--Continued } \\
\hline \multirow[t]{12}{*}{$6-25-91$} & 0945 & 26.75 & 1.06 & $6-25-91$ & 1355 & 30.92 & 0.37 \\
\hline & 1005 & 27.08 & 1.53 & & 1415 & 31.25 & .23 \\
\hline & 1028 & 27.93 & 1.25 & & 1435 & 31.58 & .32 \\
\hline & 1050 & 27.83 & 1.53 & & 1515 & 32.25 & .14 \\
\hline & 1110 & 28.17 & 1.02 & & 1600 & 33.00 & .19 \\
\hline & 1130 & 28.50 & .93 & & 1620 & 33.33 & .14 \\
\hline & 1150 & 28.83 & .83 & & 1640 & 33.67 & .23 \\
\hline & 1210 & 29.17 & .65 & & 1700 & 34.00 & .14 \\
\hline & 1230 & 29.50 & .56 & & 1720 & 34.33 & .56 \\
\hline & 1250 & 29.83 & .23 & & 1740 & 34.67 & .09 \\
\hline & 1314 & 30.23 & .37 & & 1800 & 35.00 & .09 \\
\hline & 1330 & 30.50 & .60 & & & & \\
\hline
\end{tabular}

\begin{tabular}{|c|c|c|c|c|c|c|c|}
\hline \multirow[t]{23}{*}{$6-26-91$} & 0620 & 47.33 & 0.05 & \multirow[t]{12}{*}{$6-26-91$} & 1920 & 60.33 & 2.92 \\
\hline & 1200 & 53.00 & .05 & & 1940 & 60.67 & 3.06 \\
\hline & 1220 & 53.33 & .05 & & 2000 & 61.00 & 3.01 \\
\hline & 1240 & 53.67 & .05 & & 2020 & 61.33 & 2.96 \\
\hline & 1300 & 54.00 & .09 & & 2040 & 61.67 & 2.82 \\
\hline & 1320 & 54.33 & .14 & & 2100 & 62.00 & 2.69 \\
\hline & 1340 & 54.67 & .14 & & 2120 & 62.33 & 2.59 \\
\hline & 1400 & 55.00 & .14 & & 2140 & 62.67 & 2.50 \\
\hline & 1430 & 55.50 & .19 & & 2200 & 63.00 & 2.45 \\
\hline & 1440 & 55.67 & .37 & & 2220 & 63.33 & 2.45 \\
\hline & 1500 & 56.00 & .46 & & 2300 & 64.00 & 2.32 \\
\hline & 1520 & 56.33 & .97 & & 2330 & 64.50 & 2.22 \\
\hline & 1540 & 56.67 & 1.39 & & 2400 & 65.00 & 1.85 \\
\hline & 1600 & 57.00 & 1.02 & $6-27-91$ & 0200 & 67.00 & 2.08 \\
\hline & 1620 & 57.33 & 1.39 & & 0300 & 68.00 & 1.99 \\
\hline & 1640 & 57.67 & 1.81 & & 0500 & 70.00 & 1.20 \\
\hline & 1700 & 58.00 & 2.36 & & 0520 & 70.50 & 1.20 \\
\hline & 1720 & 58.33 & 2.59 & & 0630 & 71.50 & .83 \\
\hline & 1740 & 58.67 & 2.73 & & 0700 & 72.00 & .74 \\
\hline & 1800 & 59.00 & 1.62 & & 0730 & 72.50 & .65 \\
\hline & 1820 & 59.33 & 2.64 & & 0800 & 73.00 & .65 \\
\hline & 1840 & 59.67 & 2.64 & & 0830 & 73.50 & .65 \\
\hline & 1900 & 60.00 & 3.19 & & 0900 & 74.00 & .51 \\
\hline
\end{tabular}


Table 7.--Unit times and concentrations at the indicated locations for the dye injection at Marmet Dam--Continued

[Time is military time. Elapsed time is in percentage of hours since injection. Concentration is in micrograms per liter]

\begin{tabular}{|c|c|c|c|c|c|c|c|}
\hline Date & Time & $\begin{array}{l}\text { Elapsed } \\
\text { time }\end{array}$ & Concentration & Date & Time & $\begin{array}{l}\text { Elapsed } \\
\text { time }\end{array}$ & Concentration \\
\hline & \multicolumn{7}{|c|}{ Saint Albans, Highway 25 bridge--Continued } \\
\hline \multirow{5}{*}{$6-27-91$} & 0930 & 74.50 & 0.42 & $6-27-91$ & 1200 & 77.00 & 0.23 \\
\hline & 1000 & 75.00 & .42 & & 1230 & 77.50 & .23 \\
\hline & 1030 & 75.50 & .37 & & 1510 & 80.17 & .09 \\
\hline & 1100 & 76.00 & .32 & & 1625 & 81.42 & .14 \\
\hline & 1130 & 76.50 & .32 & & & & \\
\hline \multicolumn{8}{|c|}{ Winfield Dam } \\
\hline \multirow[t]{8}{*}{$6-29-91$} & 1700 & 130.00 & 0.10 & $6-30-91$ & 2316 & 160.26 & 1.14 \\
\hline & 1800 & 131.00 & .05 & $7-1-91$ & 0016 & 161.26 & .95 \\
\hline & 1900 & 132.00 & .05 & & 0216 & 163.26 & 1.09 \\
\hline & 2000 & 133.00 & .05 & & 0316 & 164.26 & 1.19 \\
\hline & 2100 & 134.00 & .05 & & 0416 & 165.26 & 1.14 \\
\hline & 2200 & 135.00 & .05 & & 0516 & 166.27 & 1.14 \\
\hline & 2259 & 135.99 & .05 & & 0616 & 167.27 & 1.19 \\
\hline & 2359 & 136.99 & .05 & & 0716 & 168.27 & 1.24 \\
\hline \multirow{23}{*}{$6-30-91$} & 0059 & 137.99 & .05 & & 0816 & 169.27 & 1.24 \\
\hline & 0159 & 138.99 & .05 & & 0916 & 170.27 & 1.24 \\
\hline & 0259 & 139.99 & .05 & & 0930 & 170.50 & 1.24 \\
\hline & 0359 & 140.99 & .05 & & 1031 & 171.51 & 1.19 \\
\hline & 0459 & 141.99 & .05 & & 1131 & 172.52 & 1.14 \\
\hline & 0559 & 142.99 & .05 & & 1232 & 173.53 & 1.14 \\
\hline & 0659 & 143.99 & .05 & & 1332 & 174.54 & 1.14 \\
\hline & 0759 & 144.98 & .10 & & 1534 & 176.56 & 1.05 \\
\hline & 0859 & 145.98 & .14 & & 1735 & 178.58 & .90 \\
\hline & 0959 & 146.98 & .19 & & 1936 & 180.60 & .90 \\
\hline & 1059 & 147.98 & 19 & & 2000 & 181.00 & .71 \\
\hline & 1159 & 148.98 & .29 & & 2101 & 182.01 & .76 \\
\hline & 1259 & 149.98 & .43 & & 2201 & 183.01 & .67 \\
\hline & 1315 & 150.25 & .43 & & 2301 & 184.02 & .67 \\
\hline & 1415 & 151.25 & .52 & $7-2-91$ & 0001 & 185.02 & .52 \\
\hline & 1515 & 152.25 & .52 & & 0102 & 186.03 & .71 \\
\hline & 1615 & 153.25 & .57 & & 0202 & 187.04 & .57 \\
\hline & 1715 & 154.25 & .57 & & 0302 & 188.04 & .57 \\
\hline & 1816 & 155.26 & .62 & & 0403 & 189.05 & .48 \\
\hline & 1916 & 156.26 & .81 & & 0704 & 192.07 & .43 \\
\hline & 2016 & 157.26 & .86 & & 0804 & 193.07 & .43 \\
\hline & 2116 & 158.26 & .76 & & 0905 & 194.08 & .43 \\
\hline & 2216 & 159.26 & .90 & & 1005 & 195.08 & .38 \\
\hline
\end{tabular}


Table 7.--Unit times and concentrations at the indicated locations for the dye injection at Marmet Dam-Continued

[Time is military time. Elapsed time is in percentage of hours since injection. Concentration is in micrograms per liter]

\begin{tabular}{|c|c|c|c|c|c|c|c|}
\hline Date & Time & $\begin{array}{c}\text { Elapsed } \\
\text { time }\end{array}$ & Concentration & Date & Time & $\begin{array}{c}\text { Elapsed } \\
\text { time }\end{array}$ & Concentration \\
\hline \multicolumn{8}{|c|}{ Winfield Dam-Continued } \\
\hline \multirow[t]{10}{*}{$7-2-91$} & 1105 & 196.09 & 0.38 & $7-2-91$ & 2317 & 208.28 & 0.19 \\
\hline & 1507 & 200.11 & .29 & $7-3-91$ & 0017 & 209.28 & .19 \\
\hline & 1607 & 201.12 & .24 & & 0117 & 210.29 & .19 \\
\hline & 1615 & 201.25 & .29 & & 0217 & 211.29 & .19 \\
\hline & 1715 & 202.25 & .24 & & 0318 & 212.30 & .14 \\
\hline & 1816 & 203.26 & .24 & & 0418 & 213.30 & .14 \\
\hline & 1916 & 204.26 & .24 & & 0619 & 215.31 & .14 \\
\hline & 2016 & 205.27 & .24 & & 0719 & 216.31 & .14 \\
\hline & 2116 & 206.27 & .24 & & 0819 & 217.32 & .10 \\
\hline & 2217 & 207.28 & .19 & & 1120 & 220.33 & .05 \\
\hline
\end{tabular}


Table 8.--Daily mean discharge and water-surface elevation at the indicated U.S. Geological Survey streamflow-gaging stations from June 20 through July 4, 1991 (discharge and stage are not available for all locations)

[Discharge is in cubic feet per second. Elevation is for water surface in feet above sea level]

\begin{tabular}{|c|c|c|c|c|c|}
\hline Date & Discharge & Elevation & Date & Discharge & Elevation \\
\hline \multicolumn{6}{|c|}{03192000 Gauley River above Belva } \\
\hline $6-20-91$ & 349 & 670.62 & $6-28-91$ & 165 & 670.17 \\
\hline $6-21-91$ & 289 & 670.49 & $6-29-91$ & 142 & 670.11 \\
\hline $6-22-91$ & 297 & 670.50 & $6-30-91$ & 136 & 670.09 \\
\hline $6-23-91$ & 266 & 670.44 & $7-1-91$ & 132 & 670.09 \\
\hline $6-24-91$ & 208 & 670.29 & $7-2-91$ & 140 & 670.10 \\
\hline $6-25-91$ & 183 & 670.22 & $7-3-91$ & 183 & 670.22 \\
\hline $6-26-91$ & 188 & 670.24 & $7-4-91$ & 328 & 670.52 \\
\hline $6-27-91$ & 175 & 670.20 & & & \\
\hline \multicolumn{6}{|c|}{03193000 Kanawha River at Kanawha Falls } \\
\hline $6-20-91$ & 6,860 & 625.47 & $6-28-91$ & 3,700 & 624.31 \\
\hline $6-21-91$ & 7,720 & 625.76 & $6-29-91$ & 3,610 & 624.27 \\
\hline $6-22-91$ & 7,220 & 625.59 & $6-30-91$ & 3,940 & 624.41 \\
\hline $6-23-91$ & 5,730 & 625.08 & $7-1-91$ & 3,920 & 624.40 \\
\hline $6-24-91$ & 5,540 & 625.01 & $7-2-91$ & 2,790 & 623.88 \\
\hline $6-25-91$ & 4,900 & 624.79 & $7-3-91$ & 3,940 & 624.39 \\
\hline $6-26-91$ & 4,900 & 624.78 & $7-4-91$ & 4,210 & 624.51 \\
\hline $6-27-91$ & 4,390 & 624.59 & & & \\
\hline
\end{tabular}

03193700 Kanawha River at London, upstream of dam

6-20-91

6-21-91

$6-22-91$

6-23-91

6-24-91

6-25-91

$6-26-91$

$6-27-91$

6-20-91

$6-21-91$

6-22-91

6-23-91

6-24-91

6-25-91

6-26-91

6-27-91

$\begin{array}{rr}613.52 & 6-28-91 \\ 613.72 & 6-29-91 \\ 613.58 & 6-30-91 \\ 613.56 & 7-1-91 \\ & \\ 613.70 & 7-2-91 \\ 613.63 & 7-3-9 \\ 613.68 & 7-4-91 \\ 613.51 & \end{array}$

$6-28-91$

30-91

7-1-91

7-2-91

7-3-91

$-4-91$

613.55

613.62

613.73

613.78

613.53

613.61

613.61

03193701 Kanawha River at London, downstream of dam

591.15

591.18

6-28-91

6-29-91

590.77

591.27

6-30-91

7-1-91

591.23

7-2-91

7-3-91

7-4-91
590.69

590.67

590.65

590.65 
Table 8.--Daily mean discharge and water-surface elevation at the indicated U.S. Geological Survey streamflow-gaging stations from June 20 through July 4, 1991 (discharge and stage are not available for all locations)--Continued

[Discharge is in cubic feet per second. Elevation is for water surface in feet above sea level]

\begin{tabular}{ll|l}
\hline Date Discharge $\quad$ Elevation & Date Discharge Elevation \\
\hline
\end{tabular}

6-20-91

6-21-91

6-22-91

6-23-91

6-24-91

6-25-91

6-26-91

$6-27-91$

6-20-91

6-21-91

6-22-91

6-23-91

6-24-91

6-25-91

6-26-91

6-27-91

6-20-91

6-21-91

6-22-91

6-23-91

6-24-91

6-25-91

6-26-91

6-27-91

6-20-91

6-21-91

6-22-91

6-23-91

6-24-91

6-25-91

6-26-91

6-27-91

03193800 Kanawha River at Marmet, upstream of dam

$\begin{array}{rrr}590.26 & 6-28-91 & 590.31 \\ 590.27 & 6-29-91 & 590.30 \\ 590.26 & 6-30-91 & 590.32 \\ 590.22 & 7-1-91 & 590.34 \\ & & \\ 590.30 & 7-2-91 & 590.28 \\ 590.24 & 7-3-91 & 590.30 \\ 590.33 & 7-4-91 & 590.35\end{array}$

03193805 Kanawha River at Marmet, downstream of dam

$\begin{array}{rrr}567.06 & 6-28-91 & 566.04 \\ 566.94 & 6-29-91 & 566.05 \\ 566.92 & 6-30-91 & 566.06 \\ 566.42 & 7-1-91 & 566.11 \\ & & \\ 566.27 & 7-2-91 & 566.03 \\ 566.19 & 7-3-91 & 566.14 \\ 566.19 & 7-4-91 & 566.10 \\ 566.13 & & \end{array}$

03197000 Elk River at Queen Shoals

$\begin{array}{rrrrr}176 & 608.01 & 6-28-91 & 102 & 607.80 \\ 188 & 608.05 & 6-29-91 & 87 & 607.75 \\ 281 & 608.25 & 6-30-91 & 78 & 607.71 \\ 348 & 608.38 & 7-1-91 & 71 & 607.69 \\ & & & & \\ 231 & 608.15 & 7-2-91 & 66 & 607.67 \\ 182 & 608.03 & 7-3-91 & 85 & 607.74 \\ 149 & 607.95 & 7-4-91 & 82 & 607.73 \\ 122 & 607.86 & & & \end{array}$

03197990 Kanawha River at Charleston, auxiliary gage

$\begin{array}{lrl}566.33 & 6-28-91 & 566.05 \\ 566.18 & 6-29-91 & 566.05 \\ 566.17 & 6-30-91 & 566.06 \\ 566.10 & 7-1-91 & 566.06 \\ 566.05 & 7-2-91 & \\ 566.06 & 7-3-91 & 566.08 \\ 566.08 & 7-4-91 & 566.12 \\ 566.04 & & 566.05\end{array}$


Table 8.--Daily mean discharge and water-surface elevation at the indicated U.S. Geological Survey streamflow-gaging stations from June 20 through July 4, 1991 (discharge and stage are not available for all locations)--Continued

[Discharge is in cubic feet per second. Elevation is for water surface in feet above sea level]

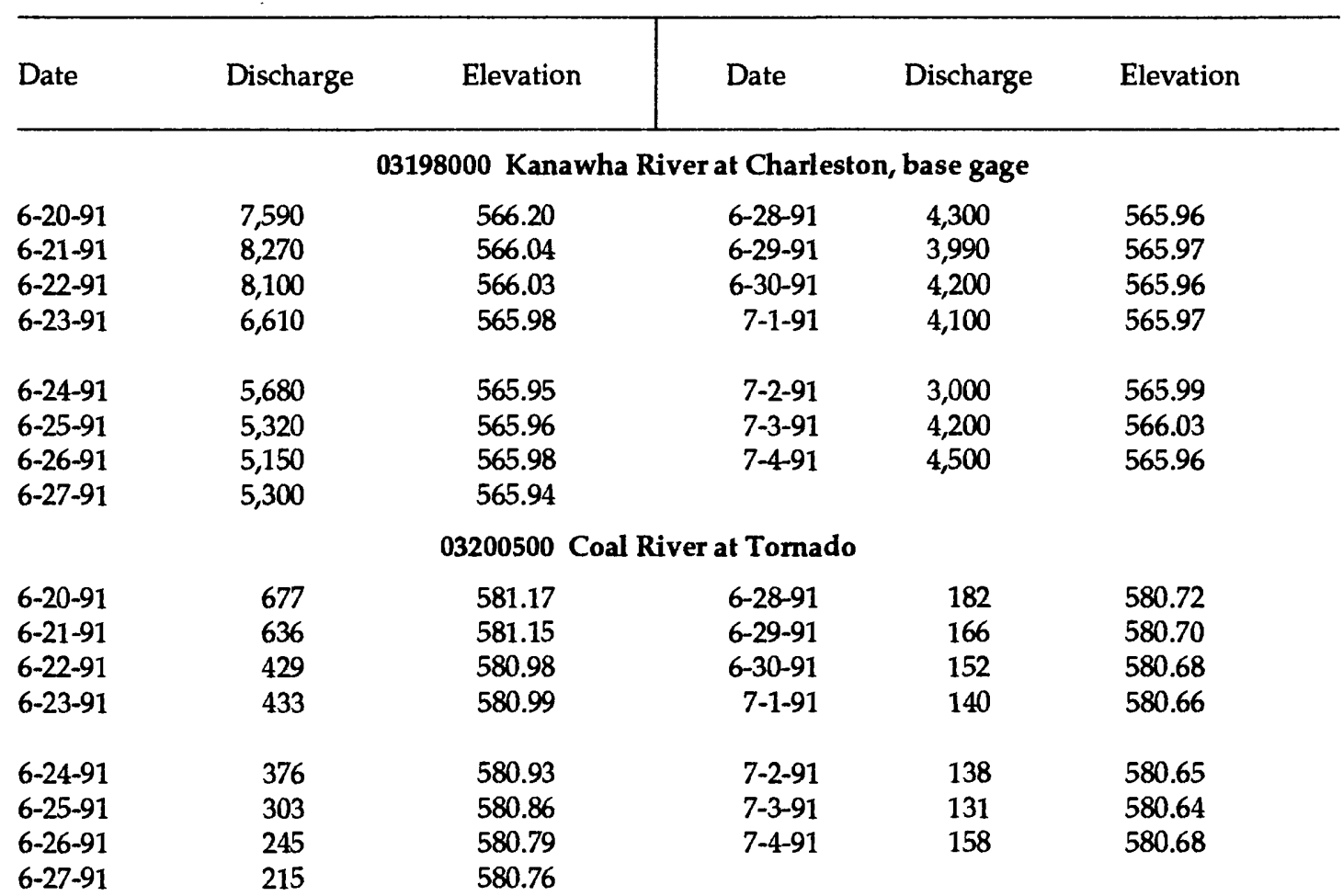

03201301 Kanawha River at Winfield, upstream of dam

6-20-91

$6-21-91$

$6-22-91$

6-23-91

6-24-91

$6-25-91$

6-26-91

6-27-91

6-20-91

6-21-91

6-22-91

6-23-91

6-24-91

6-25-91

6-26-91

6-27-91

566.08
565.90
565.89
565.87
565.91
565.92
565.93
565.91

6-28-91

6-29-91

6-30-91

7-1-91

$7-2-91$

$7-3-91$

7-4-91

565.94

565.96

565.94

565.95

565.98

566.00

565.94

03201305 Kanawha River at Winfield, downstream of dam

$\begin{array}{rrr}539.96 & 6-28-91 & 539.16 \\ 539.60 & 6-29-91 & 539.02 \\ 539.55 & 6-30-91 & 538.97 \\ 539.60 & 7-1-91 & 539.19 \\ 539.09 & & \\ 539.22 & 7-2-91 & 538.90 \\ 539.40 & 7-3-91 & 539.17 \\ 539.12 & 7-4-91 & 539.32\end{array}$


Table 8.--Daily mean discharge and water-surface elevation at the indicated U.S. Geological Survey streamflow-gaging stations from June 20 through July 4, 1991 (discharge and stage are not available for all locations)--Continued

[Discharge is in cubic feet per second. Elevation is for water surface in feet above sea level]

\begin{tabular}{|c|c|c|c|c|c|}
\hline Date & Discharge & Elevation & Date & Discharge & Elevation \\
\hline \multicolumn{6}{|c|}{03201500 Ohio River at Point Pleasant } \\
\hline $\begin{array}{l}6-20-91 \\
6-21-91 \\
6-22-91 \\
6-23-91\end{array}$ & & $\begin{array}{l}538.88 \\
538.62 \\
538.63 \\
538.98\end{array}$ & $\begin{array}{r}6-28-91 \\
6-29-91 \\
6-30-91 \\
7-1-91\end{array}$ & & $\begin{array}{l}538.82 \\
538.70 \\
538.62 \\
538.84\end{array}$ \\
\hline $\begin{array}{l}6-24-91 \\
6-25-91 \\
6-26-91 \\
6-27-91\end{array}$ & & $\begin{array}{l}538.61 \\
538.79 \\
538.95 \\
538.68\end{array}$ & $\begin{array}{l}7-2-91 \\
7-3-91 \\
7-4-91\end{array}$ & & $\begin{array}{l}538.58 \\
538.81 \\
538.99\end{array}$ \\
\hline
\end{tabular}

